\title{
Changes in domestic heating fuel use in Greece: effects on atmospheric chemistry and radiation
}

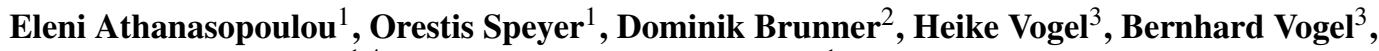 \\ Nikolaos Mihalopoulos ${ }^{1,4}$, and Evangelos Gerasopoulos ${ }^{1}$ \\ ${ }^{1}$ Institute of Environmental Research and Sustainable Development (IERSD), National Observatory of Athens (NOA), \\ Athens 152 36, Greece \\ ${ }^{2}$ Laboratory for Air Pollution/Environmental Technology (EMPA), 8600 Dübendorf, Switzerland \\ ${ }^{3}$ Karlsruhe Institute of Technology (KIT), 76344 Eggenstein-Leopoldshafen, Germany \\ ${ }^{4}$ Environmental Chemistry Processes Laboratory, Department of Chemistry, University of Crete, Heraklion, \\ P.O. Box 2208, 71003, Greece
}

Correspondence to: Eleni Athanasopoulou (eathana@noa.gr)

Received: 13 February 2017 - Discussion started: 15 March 2017

Revised: 27 June 2017 - Accepted: 2 August 2017 - Published: 8 September 2017

\begin{abstract}
For the past 8 years, Greece has been experiencing a major financial crisis which, among other side effects, has led to a shift in the fuel used for residential heating from fossil fuel towards biofuels, primarily wood. This study simulates the fate of the residential wood burning aerosol plume (RWB smog) and the implications on atmospheric chemistry and radiation, with the support of detailed aerosol characterization from measurements during the winter of 20132014 in Athens. The applied model system (TNO-MACC_II emissions and COSMO-ART model) and configuration used reproduces the measured frequent nighttime aerosol spikes (hourly $\mathrm{PM}_{10}>75 \mu \mathrm{g} \mathrm{m}^{-3}$ ) and their chemical profile (carbonaceous components and ratios). Updated temporal and chemical RWB emission profiles, derived from measurements, were used, while the level of the model performance was tested for different heating demand (HD) conditions, resulting in better agreement with measurements for $T_{\min }<$ $9{ }^{\circ} \mathrm{C}$. Half of the aerosol mass over the Athens basin is organic in the submicron range, of which $80 \%$ corresponds to RWB (average values during the smog period). Although organic particles are important light scatterers, the direct radiative cooling of the aerosol plume during wintertime is found low (monthly average forcing of $-0.4 \mathrm{~W} \mathrm{~m}^{-2}$ at the surface), followed by a minor feedback to the concentration levels of aerosol species. The low radiative cooling of a period with such intense air pollution conditions is attributed to the timing of the smog plume appearance, both directly (longwave
\end{abstract}

radiation increases during nighttime) and indirectly (the mild effect of the residual plume on solar radiation during the next day, due to removal and dispersion processes).

\section{Introduction}

Biomass has been traditionally used as a fuel for residential heating in several regions with cold climates, such as the Alpine mountain range and Scandinavia (Yttri et al., 2005; Molnar et al., 2005; Puxbaum et al., 2007; Herich et al., 2014). The European incentives to use biomass fuels, under the assumption of biomass carbon neutrality, have caused a further increase in wood burning for heating purposes in several European cities (Bari et al., 2011; Gu et al., 2013; Waked et al., 2014; Hovorka et al., 2015). Along with this trend, the financial crisis in Europe during the past 9 years has brought about a significant increase in the market price of conventional fuels, primarily due to very high taxation. In Greece, the respective increase on the non-solid fuel price was in the range of 40-60\%. The high market price together with the limited financial capacity of many households has resulted in an excessive use of biomass for domestic heating (Sarigiannis et al., 2014; Fourtziou et al., 2017).

Several studies have focused on the impacts of residential wood burning (RWB) emissions on air quality. Fuller et al. (2013) reported on aerosol $\left(\mathrm{PM}_{10}\right)$ contributions 
from residential wood burning (hereafter also called "RWB smog") in three major European cities: London, Paris and Berlin and found that, during winter, RWB makes an important contribution to breaches of the daily mean EU limit and $\mathrm{PM}_{10}$ contribution may surpass that of road traffic. In Portugal, wood combustion is estimated to comprise $60 \%$ of residential energy use but to account for almost $99 \%$ of domestic $\mathrm{PM}_{10}$ emissions (Borrego et al., 2010). An emission inventory constructed for Greece by Fameli and Assimakopoulos (2016) showed that, regarding residential emissions, $67 \%$ of the emitted $\mathrm{CO}$ in Greece originates from fireplaces. At the European level (EU-28), fuel combustion in the residential combustion sector (commercial, institutional and household) is the major source of primary $\mathrm{PM}_{2.5}$ and $\mathrm{PM}_{10}$ as well as black carbon (BC) emissions contributing 56,40 and $46 \%$, respectively (EEA, 2016). Residential combustion (mainly wood) accounts for 3-20\% (2-30\%) of ambient annual mean $\mathrm{PM}_{10}\left(\mathrm{PM}_{2.5}\right)$ levels in different European regions, with maximum contributions of up to almost $30 \%$ $(30 \%)$ for the winter period mean value (Viana et al., 2016).

The type of areas examined regarding wood burning impacts on air quality may range from a specific residential area or a suburb (Hellen et al., 2008 and Yli-Tuomi et al., 2015) to a large city such as London (Fuller et al., 2014; Young et al., 2015) and to a regional level, such as Flanders, Belgium (Maenhaut et al., 2012). They all agree on a substantial contribution of RWB to PM mass, even when the use is for secondary heating. Wood combustion in open fireplaces emits a mixture of soot (often used interchangeably with BC and/or EC; e.g., Maricq, 2014) and organic carbon (OC), with the latter being the major component of RWB aerosol (Bølling et al., 2009). The contribution of wood combustion to OC is found to be up to $41 \%$ of the OC in the $\mathrm{PM}_{10}$ fraction during the wintertime in Zurich (Szidat et al., 2007) and up to $50 \%$ in Lombardy (Piazzalunga et al., 2011). In Switzerland, during winter, BC from RWB contributes on average $24-33 \%$ of measured BC levels, which is a noticeably high fraction as the contribution of wood burning to the total final energy consumption is less than $4 \%$ (Herich et al., 2014). Saffari et al. (2013) showed the connection between wood burning and increased levels of PM during the winter in Thessaloniki, while Sarigiannis et al. (2014) further quantified an average increase in $\mathrm{PM}_{10}$ (and $\mathrm{PM}_{2.5}$ ) due to biomass burning of up to $43 \mu \mathrm{g} \mathrm{m}^{-3}$. In Athens, the intense use of open fireplaces and woodstoves for domestic heating during the last years has caused notable increases in the ambient PM concentrations, with the contribution from biomass combustion reaching up to $70 \%$ of the PM mass concentration during extreme pollution episodes. The relevant 5 -year measurements study also showed an increase of $80 \%$ in $\mathrm{BC}$ due to increased wood burning (Paraskevopoulou et al., 2014). The chemical footprint of these smog events has been well established via specialized aerosol measurements, e.g., significant correlations between $\mathrm{PM}_{2.5}$ and levoglucosan, or high fine mode particulate potassium, demonstrating that, during wintertime, wood burning in Athens could be responsible for $\mathrm{PM}_{2.5}$ levels higher than $45 \mu \mathrm{g} \mathrm{m}^{-3}$ (Fourtziou et al., 2017; Paraskevopoulou et al., 2014).

Modeling applications devoted to RWB are less numerous and primarily focused on source apportionment and sensitivity to emissions. Simpson et al. (2007) pointed out that the missing wood burning contributions may explain the discrepancies between simulations and observations for wintertime OC. Fountoukis et al. (2014) estimated a decrease in fine organic aerosol (OA; up to $60 \%$ in urban and suburban areas during winter), elemental carbon (30-50\% in large parts of Europe) and $\mathrm{PM}_{2.5}$ mass (15-40\% during winter in continental Europe) by replacing current residential wood combustion technologies with pellet stoves, underlining the high sensitivity of these model results to the relevant changes in the RWB emissions. This increasing importance of RWB is also recognized by the revised higher estimates of the latest version of the TNO emission database (Denier van der Gon et al., 2015), as far as particulate matter is concerned. The inventory indicated that about half of the total $\mathrm{PM}_{2.5}$ emissions in Europe are carbonaceous aerosol and identified RWB as the largest organic aerosol source. Moreover, the authors note that while emissions of particulate matter or carbonaceous aerosols are notoriously uncertain, a revised bottom-up inventory was constructed with emphasis on residential wood combustion, which was previously significantly underestimated.

There can be a multitude of impacts of the increasing carbonaceous aerosol contribution to PM as a result of increasing importance of RWB. Exposure to ambient particulate matter has been associated with a range of negative health effects, including increased morbidity and mortality from pulmonary and cardiovascular diseases (Bølling et al., 2009). Recent epidemiologic studies have displayed the risks of exposure to increased levels of total carbon (TC), a major constituent of wood smoke, revealing notable associations with the aforementioned diseases (Ostro et al., 2009; Lipsett et al., 2011; Krall et al., 2013). In a systematic review from short-term epidemiological and cohort studies, it was found that $\mathrm{BC}$ is a better indicator of harmful particulate substances from combustion sources than undifferentiated particulate matter mass and it may operate as a universal carrier of a wide variety of chemicals of varying toxicity (Janssen et al., 2012).

Other important aspects of wood burning particles and other aerosols are their direct and indirect effects on atmospheric physics and dynamics. Carbonaceous species, composed of both light-absorbing $\mathrm{BC}$ and light-scattering OC, are well recognized contributors to radiative forcing (RF; Novakov et al., 2005), and the fraction of OC/EC (or OC/BC) becomes decisive with respect to the sign of the contribution (Bäumer et al., 2007). BC has been considered as the second most important climate forcing agent from human sources in the present-day atmosphere, behind carbon dioxide (Bond et al., 2013). Several studies concentrated on the direct ra- 
diative effect (DRE) of aerosols and their impact on ground temperature (Vogel et al., 2009; Stanelle et al., 2010; Bangert et al., 2012; Lungren et al., 2013; Athanasopoulou et al., 2013). Severe winter haze events over the heavily polluted North China Plain and over eastern China were found to have a significant negative RF ranging from 20 to $140 \mathrm{~W} \mathrm{~m}^{-2}$ (Gao et al., 2015; Zhang et al., 2015). Focusing on a carbonaceousrich aerosol loading induced by wildfires in Greece, Athanasopoulou et al. (2014) revealed a negative impact on the surface radiative budget on the order of $10 \mathrm{~W} \mathrm{~m}^{-2}$ (3-day average) and a reduction of surface temperature by $0.5 \mathrm{~K}$ over land. The radiative effect of aerosols on longwave radiation is less examined. Stanelle et al. (2010) concentrated on dust episodes over West Africa and found an average increase of $70 \mathrm{~W} \mathrm{~m}^{-2}$ for the longwave radiative effect. Comparing the aerosol optical depth (at $450 \mathrm{~nm}$ ) with the surface longwave flux, he found the relationship to be nonlinear in contrast to the shortwave case. Panicker et al. (2008) found a positive surface forcing of $6-9 \mathrm{~W} \mathrm{~m}^{-2}$ over an urban environment in Prune, India. Finally, aerosols have an indirect effect on meteorology and climate by acting as cloud condensation nuclei (CCN) and ice nuclei (IN) in aerosol-cloud interactions (Kanakidou et al., 2005; Bangert et al., 2011). To the best of our knowledge, there has been no study so far addressing the direct radiative effects of RWB smog.

The current study focuses on the winter of 2013-2014 in Athens, when several severe RWB smog events were recorded. The comprehensive, online-coupled, modeling system COSMO-ART (COnsortium for SMall-scale MOdelingAerosols and Reactive Trace gases) was used to quantify the effect of wood burning on aerosol levels and aerosol chemistry as well as on radiation during this period. Detailed chemical measurements of concentrations, speciation and fractions related strictly to wood burning were available from the longest winter measuring campaign of RWB smog to date (e.g., Paraskevopoulou et al., 2014; Fourtziou et al., 2017). Within this paper we want to address the following topics: 1. assessment of the emission data from RWB, 2. contribution of RWB to the total aerosol load and chemistry, 3. calculation of the optical properties of RWB aerosol and 4. impact of RWB smog on radiation and feedbacks on atmospheric composition.

\section{Data and methods}

\subsection{Experimental data}

Since winter 2012, several intensive campaigns have been designed and carried out at the official aerosol monitoring site of the National Observatory of Athens (NOA), at its central premises in Thissio $\left(37.97^{\circ} \mathrm{N}, 23.72^{\circ} \mathrm{E}\right)$, in Athens' city center. Thissio is an urban background site, representative of Athens' average atmospheric load. Details of the site are provided in Paraskevopoulou et al. (2015) and Fourtziou et al. (2017). For the needs of this modeling study, measurements were taken from the campaign in winter 2013-2014 (16 December 2013 to 21 February 2014), during which unique datasets of wood burning indicators were acquired (Fourtziou et al., 2017).

In particular, a time series of hourly $\mathrm{PM}_{10}$ is used here, taken from a $\mathrm{PM}_{10}$ beta-attenuation analyzer. The $\mathrm{PM}_{1}$ chemical composition of non-refractory aerosol particles (organics, sulfate, nitrate, ammonium and chloride) was obtained by an Aerosol Chemical Speciation Monitor (ACSM). $\mathrm{PM}_{1} \mathrm{OC}$ was obtained via the thermal optical transmission technique, using a Sunset Laboratory Inc. (Oregon) carbon analyzer (see Paraskevopoulou et al., 2014) and $\mathrm{PM}_{1} \mathrm{BC}$ by a portable aethalometer (AE42, Magee Scientific; at seven wavelengths: 370, 470, 520, 590, 660, 880 and $950 \mathrm{~nm}$ ). Details of the aforementioned measurements and techniques for the specific campaign can be found in Fourtziou et al. (2017). Among the results described there (and references therein) is the decomposition of the $\mathrm{BC}$ time series into $\mathrm{BC}$ associated with fossil fuel $\left(\mathrm{BC}_{\mathrm{ff}}\right)$ and wood burning $\left(\mathrm{BC}_{\mathrm{wb}}\right)$, enabled by the wavelength dependence of the BC measurements. Standard meteorological parameters (relative humidity, temperature, rain, wind speed and direction) are measured on a routine basis at the station.

\subsection{Model framework and setup}

COSMO-ART is a regional atmospheric model which couples online meteorology, chemistry and aerosol dynamics. COSMO is the operational numerical weather prediction model of the German and other European weather services (Baldauf et al., 2011), while a model version for regional climate modeling is also available by the Climate Limitedarea Modelling Community (COSMO-CLM; Rockel et al., 2008). ART is the chemistry extension of COSMO. Detailed descriptions of the model, the physical-chemical characteristics of the aerosol modes, and the parameterizations of interactions of aerosols with radiation, temperature, and cloud and ice condensation nuclei are given in Vogel et al. (2009), Bangert et al. (2011, 2012) and Rieger et al. (2014). The model domain chosen in this study is the extended area of Greece, centered on Athens, which is the area of interest. The setup of the current model application (Table 1) is largely based on the pilot study of the COSMO-ART application over the same domain (Athanasopoulou et al., 2014). The simulations were carried out for the period 17 December 2013 to 22 January 2014, providing hourly outputs directly comparable with the in situ, surface-level measurements (Sect. 2.1). The first 2 days of all model runs (Table 2) were used as a spin-up to dampen the effect of the uniform (in space) initial conditions (e.g., for $\mathrm{SO}_{2}$ and aerosol species).

Hourly anthropogenic emissions of gases $\left(\mathrm{CO}, \mathrm{NH}_{3}\right.$, NMVOC, $\mathrm{NO}_{x}$ and $\left.\mathrm{SO}_{2}\right)$ and aerosols $\left(\mathrm{PM}_{10}, \mathrm{PM}_{2.5}\right)$ are based on the TNO-MACC_II emission inventory for Europe (van der Gon et al., 2010; Kuenen et al., 2011, 2014; Denier 
Table 1. Main characteristics of the COSMO-ART configuration and the current model setup. Italic fonts indicate emissions not considered in the current model runs.

\begin{tabular}{|c|c|}
\hline Formulation/mechanisms & COSMO-ART \\
\hline Chemical mechanisms & $\begin{array}{l}\text { Gaseous chemistry: RADMKA (Stockwell et al., 1990; Vogel et al., 2009). } \\
\text { Inorganic aerosol chemistry: ISORROPIA II (Fountoukis and Nenes, 2007). } \\
\text { Organic aerosol chemistry: VBS (Athanasopoulou et al., 2013). } \\
\text { Wet scavenging and liquid-phase chemistry (Knote and Brunner, 2013). }\end{array}$ \\
\hline Dynamic aerosol processes & $\begin{array}{l}\text { Modal Aerosol Dynamics Model for Europe: MADEsoot (Riemer et al., 2003) } \\
\text { (11 overlapping log-normally distributed modes). }\end{array}$ \\
\hline Interaction between aerosols and meteorology & $\begin{array}{l}\text { Aerosol effects on radiation and temperature: GRAALS (Ritter and Geleyn, 1992). } \\
\text { Aerosol activation (CCN) and ice nucleation (IN) parameterizations (Bangert et al., 2011, 2012). }\end{array}$ \\
\hline Initial and boundary conditions & $\begin{array}{l}\text { Meteorology: COSMO model application over Europe }(7 \times 7 \mathrm{~km}) \text {, driven by the German Weather } \\
\text { Service GME global model (Majewski et al., } 2002) \text {. } \\
\text { Gaseous species }\left(\mathrm{CO}, \mathrm{HNO}_{3}, \mathrm{NH}_{3}, \mathrm{NO}_{x}, \mathrm{NO}_{3}, \mathrm{O}_{3}, \mathrm{NMVOC}\right) \text { : global outputs }\left(2.5^{\circ} \times 1.9^{\circ}\right) \text { from } \\
\text { the MOZART model }(\text { Emmons et al., } 2010) \text {. } \\
\text { Secondary aerosol species in the aged modes: } 1 \mu \mathrm{g} \mathrm{m}^{-3} \text { for sulfates, } 0.1 \mu \mathrm{g} \mathrm{m}^{-3} \text { for nitrates, } \\
0.37 \mu \mathrm{g} \mathrm{m}^{-3} \text { for ammonium and } 1 \mu \mathrm{g} \mathrm{m}^{-3} \text { for secondary organic aerosol (SOA) in the surface } \\
\text { layer* (typical background concentrations; Athanasopoulou et al., 2013). }\end{array}$ \\
\hline Input data & $\begin{array}{l}\text { Anthropogenic, agricultural emissions (prescribed): TNO-MACC_II (Denier van der Gon et al., } \\
\text { 2010; Kuenen et al., 2011, 2014). } \\
\text { Fire emissions (prescribed): GFED v.3 (van der Werf et al., 2010). } \\
\text { Biogenic activity (isoprene, } \alpha \text {-pinene, } \alpha \text {-limonene), desert dust (three aerosol modes), sea salt } \\
\text { (three aerosol modes) and DMS (dimethyl sulfide) production; pollen and volcanic ash uplift and } \\
\text { transport: online calculation (Vogel et al., 1995, 2006, 2014; Lundgren et al., 2013; Nightingale } \\
\text { et al., 2000; Zink et al., 2013). }\end{array}$ \\
\hline Vertical grid & 40 levels (from surface to ca. $23 \mathrm{~km}$; first layer is ca. $20 \mathrm{~m}$ thick) \\
\hline Horizontal domain & 18 to $30^{\circ} \mathrm{E}, 33$ to $42^{\circ} \mathrm{N}\left(0.025^{\circ} \times 0.025^{\circ}\right)$ \\
\hline
\end{tabular}

Table 2. Description of modeling runs performed by the current COSMO-ART application from 17 December 2013 to 22 January 2014.

\begin{tabular}{llll}
\hline \multicolumn{2}{l}{ Case } & Description & Objective \\
\hline 1 & Baseline & Original RWB emission data & $\begin{array}{l}\text { Evaluation of the modified emission data from RWB in } \\
\text { Greece } \\
\text { Aerosols over Athens during an intense } \\
\text { RWB smog period }\end{array}$ \\
Revised* & RWB-free* & $\begin{array}{l}\text { Emissions from all residential combustion fuels, } \\
\text { except wood } \\
\text { The interaction between aerosols and meteorology } \\
\text { is switched off }\end{array}$ & $\begin{array}{l}\text { Contribution of RWB to the total aerosol load and } \\
\text { chemistry and impact of RWB smog on radiation } \\
\text { Impact of total aerosol on radiation }\end{array}$ \\
\hline
\end{tabular}

${ }^{*}$ Modifications in residential wood combustion emissions and in aerosol optical properties (see Sects. 2.3 and 2.4).

van der Gon et al., 2011). Data are provided at high resolution $\left(7 \times 7 \mathrm{~km}^{2}\right)$ and reflect emissions from industrial sources; road (and off-road), rail, air and other transport; and waste treatment, agriculture and residential combustion.

The processing of this dataset for COSMO-ART applications includes a source-specific speciation of NMVOCs (nonmethane volatile organic compounds) and PM (BC, OA, $\mathrm{SO}_{4}$, rest), the application of time profiles (for diurnal, dayof-week and seasonal variability) and a mapping onto the simulation grid (Knote et al., 2011). For the present study, emissions representative of 2009 (latest year available in the inventory) were used with no further scaling to the simulation period. A recent study on air pollution emissions in Greece based on current data (Fameli et al., 2016) shows that, with respect to residential heating, no clear trend from 2009 to 2012 (latest available data) is evident for the consumption of different type of fuels, except for wood which is increased. With respect to the road sector, similar estimations cannot be performed, since the latest available data refer to 2010 .

Thus, in the frame of the current study, the prescribed wood combustion emissions and aerosol optical properties (Vogel et al., 2009) have been processed and revised ac- 
cording to observational findings representative of the area of interest and the wintertime periods of the ongoing crisis (Sects. 2.3 and 2.4).

\subsection{Modifications of the aerosol emissions from residential combustion}

Non-industrial (residential and agricultural) combustion is spatially distributed according to the population density and the proximity to wood (Kuenen et al., 2014). For Greece, it is calculated that almost all mass (i.e., $98 \%$ ) of the total $\mathrm{PM}_{10}$ emissions from this source category reflects wood combustion (i.e., open fireplaces and wood stoves).

Unlike the emission data for the gaseous species, which are officially submitted by Greece (EEA, 2011), the $\mathrm{PM}_{10}$ (and $\mathrm{PM}_{2.5}$ ) emission rates provided by the TNO-MACC_II emission inventory are not based on real data, but solely on model approximations (IIASA, 2012); thus, significant improvements are feasible upon real data availability. For instance, changes in the temporal emission profiles can have a great impact on the air quality model results for Europe, especially with respect to residential combustion (Denier van der Gon et al., 2011). More specifically, the diurnal profiles suggested therein for the residential combustion sector have a peak in the morning (black line in Fig. 1a), while the common practice in Greece is to use fireplaces mainly in the evening. Furthermore, space heating is more intense on weekends, which is the opposite of the respective suggested weekly variation (black line in Fig. 1b).

Therefore, both the hourly and weekly cycles applied to wood combustion emissions were revised to better match the current common practices in Greece. In particular, assuming that the temporal variation of $\mathrm{BC}_{\mathrm{wb}}$ closely follows the temporal profile of the corresponding emissions during winter when the planetary boundary layer (PBL) dynamics are moderate, hourly observations of this well-defined RWB index, normalized with respect to the average value, were used for the revision (green line in Fig. 1a). The average profile was derived from the long-term monitoring of $\mathrm{BC}$ during the 2013-2015 winter periods. In this way, the two primary peaks in the standard profile were replaced by a much more realistic profile, with an intense peak in the evening hours. In order to revise the original weekly cycle for residential wood combustion, the same data were used, but only during the peak activity period of the fireplaces (20:00-02:00 LST). A representative day-of-week cycle was derived from the observations, based on the median values (to minimize the influence of possible outliers, e.g., holiday and weekdays). Again, the weekly cycle (green line in Fig. 1b) is now consistent with the increased residential wood combustion in Athens during the weekends. It should be noted that the revised temporal cycles were applied only to the aerosol fraction of wood combustion ( $98 \%$ of total combustion aerosol emissions), while gases were assumed to be emitted in equal amounts by wood (revised profiles) and non-wood fuel com- bustion (original profiles). Thus, the final profiles were calculated from the respective weighted means.

Furthermore, the original chemical profile of aerosol emissions from non-industrial combustion $(20 \% \mathrm{BC}, 40 \% \mathrm{OA}$ and $40 \%$ others) was modified based on the chemical composition of aerosol spikes $\left(>75 \mu \mathrm{g} \mathrm{m}^{-3}\right.$, i.e., national alert value for the whole population; Joint Ministerial Decision by FEK 3272B/23-12-2013) during nighttime. Measurements show that the aerosol mass originating from fireplaces is primarily composed of OA $(80 \%)$, while the rest is equally partitioned into $\mathrm{BC}$ and other species. This doubling of the OA mass is in line with a recent study on particulate emissions, based on the latest rise in residential wood combustion in Europe (Denier van der Gon et al., 2015), and is related to the semi-volatile organic matter that is instantaneously formed after emissions are exposed to the cooler ambient temperature. Furthermore, the currently applied emission ratio of $\mathrm{BC} / \mathrm{OC}(0.12)$, derived from the measurements at Thissio, is close to the average of 11 studies $(0.16 \pm 0.05)$ on emission factors for RWB (fireplaces), presented in Szidat et al. (2007).

A representative map of the modified emission rates for the area of interest is shown in Fig. 2. These rates, combined with the temporal profiles (Fig. 1), can be transformed into the hourly emission rates from wood burning for any hour and day of a typical winter week in Athens, as presented in the revised TNO-MACC_II emission database. Given the basic proxy used for the spatial allocation of emission totals (population density), emission values have a maximum at the urban core, where aerosol emissions from RWB represent around $90 \%$ of the total value. In particular, the hourly emission rate of aerosol during a smog episode in the Athens city center is in the range of $3.5-4.5 \mathrm{~kg} \mathrm{~h}^{-1} \mathrm{~km}^{-2}$. It is possible, though, that an over-allocation of emissions in the city center occurs, as already described in previous studies (Timmermans et al., 2013; Kuenen et al., 2014).

The revised TNO database for Athens was used for the revised run of the current study (case 2 in Table 2). A comparative run using the original TNO-MACC_II database was also performed (case 1 or baseline) to evaluate the level of improvements achieved. It should be noted that an artificial increase in the mass of residential aerosol emissions due to the switch of residential heating from fossil fuels to wood burning was not attempted, as the comparison among model outputs and observations during the smog period (Sect. 3.1.1.) confirmed the magnitude of the original daily $\mathrm{PM}_{10}$ emission rates for residential combustion.

\subsection{The aerosol optical properties}

The properties of atmospheric particles (chemical composition, liquid water content, optical properties) determine their effects on short- and longwave radiation (scattering and absorption). COSMO-ART incorporates prescribed values for the single scattering albedo (SSA), extinction coefficient (in 

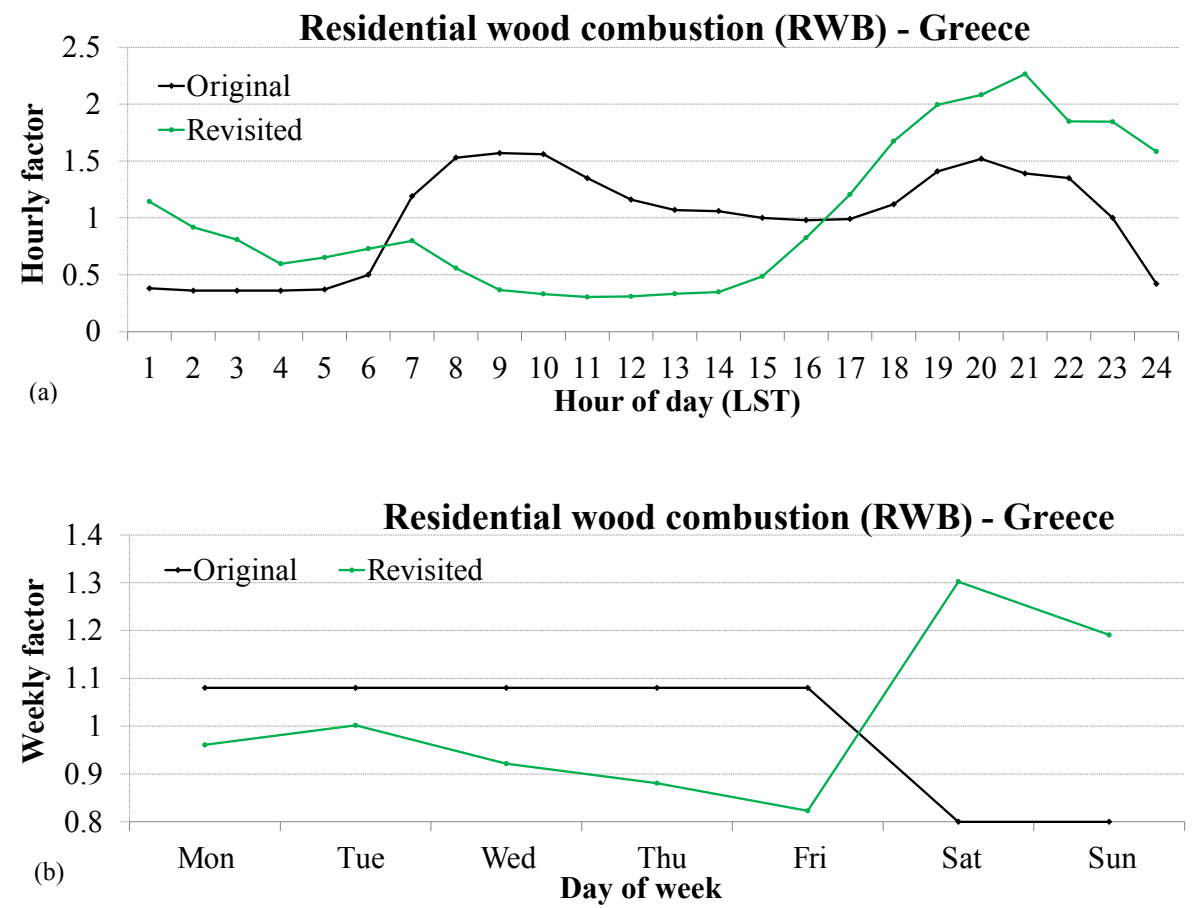

Figure 1. Original (black line) and revisited (green line) (a) diurnal and (b) weekly profiles applied to the emissions from residential wood combustion (RWB) in Greece (TNO-MACC_II database; Denier van der Gon et al., 2011). The revisited temporal profiles correspond to the mean values of the long-term measurements (2013-2015) of the wood burning fraction of black carbon ( $\left.\mathrm{BC}_{\mathrm{wb}}\right)$ in $\mathrm{Athens}$, normalized with respect to the average value of each cycle.

$\mathrm{m}^{2} \mathrm{~g}^{-1}$ ) and asymmetry factor for five ultrafine aerosol mixtures (pure soot, aged soot coated with soluble material in the nucleation and in the accumulation mode, and purely soluble mixture in the nucleation and in the accumulation mode).

For the purpose of the present study, the calculation of the aerosol optical properties is based on observational data collected in Greece during the 2013-2014 RWB smog episodes. In particular, the average surface chemical composition of ultrafine aerosols in Athens (pure soot: $2.8 \mu \mathrm{g} \mathrm{m}^{-3}$; watersoluble mixture of sulfate, nitrate, ammonium and organics: $\left.22.2 \mu \mathrm{g} \mathrm{m}^{-3}\right)$, the local relative humidity $(50-70 \%)$ and an average mixing layer height (600 ma.g.l., Gerasopoulos et al., 2017) were used to feed the OPAC software (Hess et al., 1998), which then - by applying the Mie theory provides the respective optical properties for 61 wavelengths between 0.25 and $40 \mu \mathrm{m}$ (grey lines in Fig. 3). These values have been applied to the eight wavelength bands simulated by COSMO, which cover the spectral range from 0.25 to $104.5 \mu \mathrm{m}$ (green lines in Fig. 3) and were used for case 2.

These values differ from the ones used in Vogel et al. (2009; black and red lines in Fig. 3), which is expected due to the different geographical areas and periods of interest between the two studies. The smooth reduction with increasing wavelength in the SSA of pure soot in this study, as well as the abrupt decrease from 1 to $3 \mu \mathrm{m}$ in the water-soluble aerosol modes, is consistent with the findings of Mishra et al. $(2014,2015)$ for the polluted air masses over the Mediterranean as well as with the respective model values used in the study by Takemura et al. (2002) for carbonaceous and sulfate aerosol.

\section{Results}

The winter of 2013-2014 can be characterized as relatively mild. December 2013 was the 34th coldest of the period 1897-2014 (NOA records for Athens), with a daily mean temperature of $10.7^{\circ} \mathrm{C}$ and minimum temperatures $\left(T_{\min }\right)$ from 4.9 to $11.5^{\circ} \mathrm{C}$. January 2014 , with a mean daily temperature of $12.5^{\circ} \mathrm{C}$, was the warmest January since 1897 . Daytime peaks reached values above $16^{\circ} \mathrm{C}$, while nighttime temperatures were greater than $10^{\circ} \mathrm{C}$ for $75 \%$ of the days. The coldest period of this month was 3-5 January, with $T_{\min }$ from 7.3 to $8.2{ }^{\circ} \mathrm{C}$. The relative humidity during the period was generally above $50 \%$, reaching values above $90 \%$ during several precipitation events, which took place on 26-27 and 31 December 2013 and 2, 5-6 and 15-16 January 2014 (Fig. 4a).

The wind speeds during this period were rather low (usually from the northern sector), preventing the dispersion of pollution. The average wind speed was $2.7 \mathrm{~ms}^{-1}$, with stronger winds $\left(5-8 \mathrm{~ms}^{-1}\right)$ from the north direction on 17, 27 and 31 December 2013 and 7, 15 and 19-22 January 2014. 

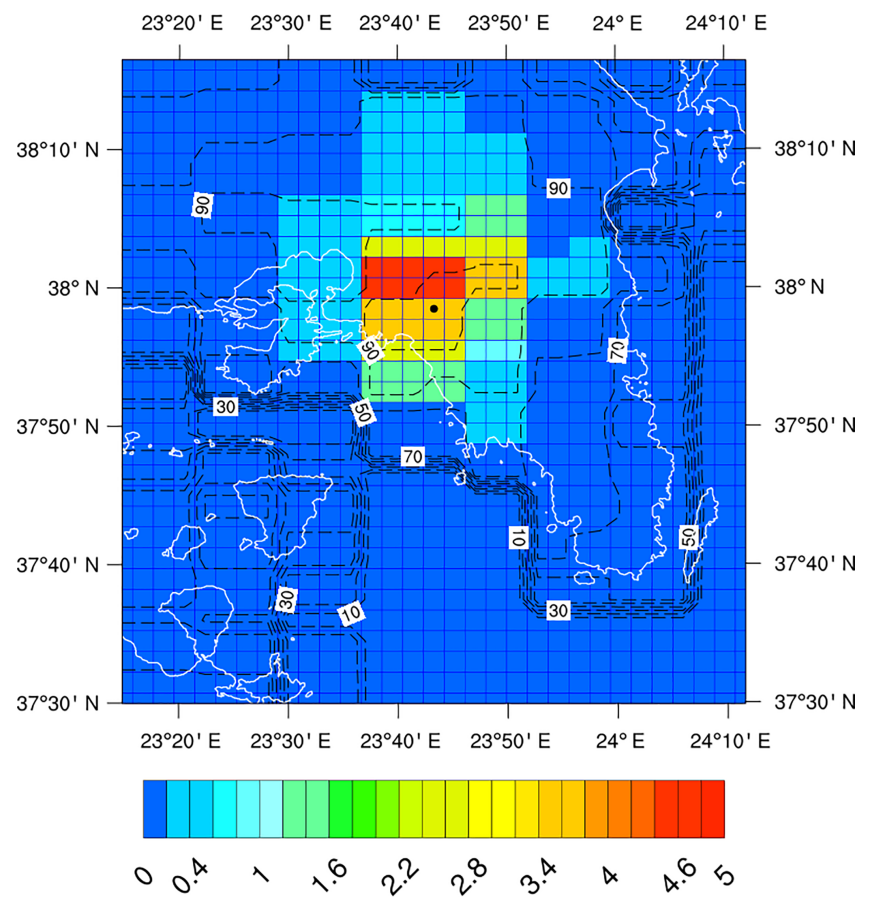

Figure 2. RWB aerosol emission rates $\left(\mathrm{kg} \mathrm{h}^{-1} \mathrm{~km}^{-2}\right.$; color contours) and their fraction of the total aerosol emissions (isolines in \%) for a night hour of a weekday (Tuesday, 21:00 UTC), as retrieved from the revised emission data (TNO-MACC_II). It is noted that the spatial resolution of the emissions $\left(0.125^{\circ} \times 0.0625^{\circ}\right)$ is coarser than that of the model configuration $\left(0.025^{\circ} \times 0.025^{\circ}\right.$; embedded grid). The city center of Athens is shown with the black mark.

An exception with strong (up to $8 \mathrm{~ms}^{-1}$ ) southeastern winds occurred on 21 January, when a Saharan dust intrusion took place. This event is well documented by satellite retrievals of aerosol optical depth (https://giovanni.sci.gsfc.nasa.gov/ giovanni/) as well as BSC-DREAM8b model outputs (http: //www.bsc.es/ESS/nmmb_bsc-dust).

These meteorological conditions favored the accumulation of smog over Athens during the period 19 December 2013-5 January 2014 (mean maximum nighttime hourly $\mathrm{PM}_{10}$ concentrations of $\left.103.7 \mu \mathrm{g} \mathrm{m}^{-3}\right)$. This time frame, excluding the rainy days mentioned above, constitutes the intense smog period of the current modeling study, analyzed in Sect. 3.1.1. An interesting case for studying aerosol spatial fields (Sect. 3.1.2) is 4-5 January (from noon to noon), as this was the most polluted smog event of the whole period (the maximum nighttime hourly $\mathrm{PM}_{10}$ concentration was measured $167.7 \mu \mathrm{g} \mathrm{m}^{-3}$ ) and showed a good model performance (the maximum nighttime hourly $\mathrm{PM}_{10}$ concentration was predicted $202.2 \mu \mathrm{g} \mathrm{m}^{-3}$ ). A mild winter day (7 January noon-8 January noon, $T_{\min }=10.6^{\circ} \mathrm{C}$ ) with low smog influence $\left(\mathrm{BC}_{\mathrm{wb}}\right.$ equals $44 \%$ of $\left.\mathrm{BC}_{\text {tot }}\right)$ according to measurements and predictions (Fig. 4c) is also examined for comparison purposes, using results from the case 3 .
The mean radiative aerosol effect under smog conditions is discussed in Sect. 3.2, together with the maximum impact during the intense smog event defined above. Cloudless conditions during this day with no interferences by cloudradiation interactions as well as with the good representation of aerosol observations gives credibility to the model results with respect to the direct radiative effects of wood burning smog and the respective feedbacks on atmospheric composition.

\subsection{Impacts of residential wood burning (RWB) on atmospheric aerosol mass and chemistry}

\subsubsection{Aerosol model performance under smog influence}

The applied model system as well as its configuration and methodology for the simulation of the smog period is examined and evaluated through (a) the reproduction of the mean and peak values of mass concentrations of $\mathrm{PM}_{10}$, submicron organic $\left(\mathrm{PM}_{1} \mathrm{OA}\right)$ and black carbon $\left(\mathrm{PM}_{1} \mathrm{BC}\right)$, and measurements; (b) the degree of correlation with the respective observations; (c) the values of representative aerosol ratios (RWB fraction, OC/BC, BC/TC, TC/PM $10, \mathrm{OA} / \mathrm{PM}_{10}$ and $\left.\mathrm{BC} / \mathrm{PM}_{10}\right)$; and (d) the reproduction of the observed diurnal cycles of $\mathrm{PM}_{10}, \mathrm{PM}_{1} \mathrm{OA}$ and $\mathrm{PM}_{1} \mathrm{BC}$. The model's ability to reproduce the mean values of mass concentrations is quantified by calculating the mean bias (MB), the correlation coefficient $\left(r^{2}\right)$ and the mean absolute normalized gross error (MANGE) for cases 1 and 2 (baseline and revised simulation). For the peak values, the paired peak estimation accuracy (PPEA) is used. A summary of the model skills is given in Tables 3-5, while the mathematical formulation of the applied statistical parameters is given in Appendix A.

The mean value of the $\mathrm{PM}_{10}$ observed during the intense smog period was $45.2 \mu \mathrm{g} \mathrm{m}^{-3}$, which is captured by case $2\left(50.8 \mathrm{\mu g} \mathrm{m}^{-3}\right)$ but overestimated by the baseline $\left(58.7 \mu \mathrm{g} \mathrm{m}^{-3}\right)$, although the total $\mathrm{PM}_{10}$ mass emitted by residential combustion is unchanged for a typical week in total. The respective mass amounts emitted during weekdays (weekends) are reduced (increased) due to the revised weekly cycles (see Fig. 1b). Given the fact that the intense smog period ( 13 days) includes only 4.5 weekend days, the differences found by the two scenarios in the average $\mathrm{PM}_{10}$ concentrations are justified. Although the MB between measurements and the two model runs is similar, the correlation of hourly data with observations is greatly improved in case 2 with an $r^{2}$ of 0.66 compared to only 0.24 in case 1 (Table 3 ). This is again related to the revisited temporal cycles of emissions, which represent the use of wood for space heating purposes in Athens in a realistic manner. In particular, the observed nighttime $\mathrm{PM}_{10}$ peaks were on average $103.6 \mu \mathrm{g} \mathrm{m}^{-3}$, which is more than 2 times higher than the mean daytime maximum $\left(47.8 \mu \mathrm{g} \mathrm{m}^{-3}\right)$. Case 1 failed to represent these values (e.g., morning PPEA equals $+173 \%$ ) due to the precrisis space heating (mainly office) during the working hours 

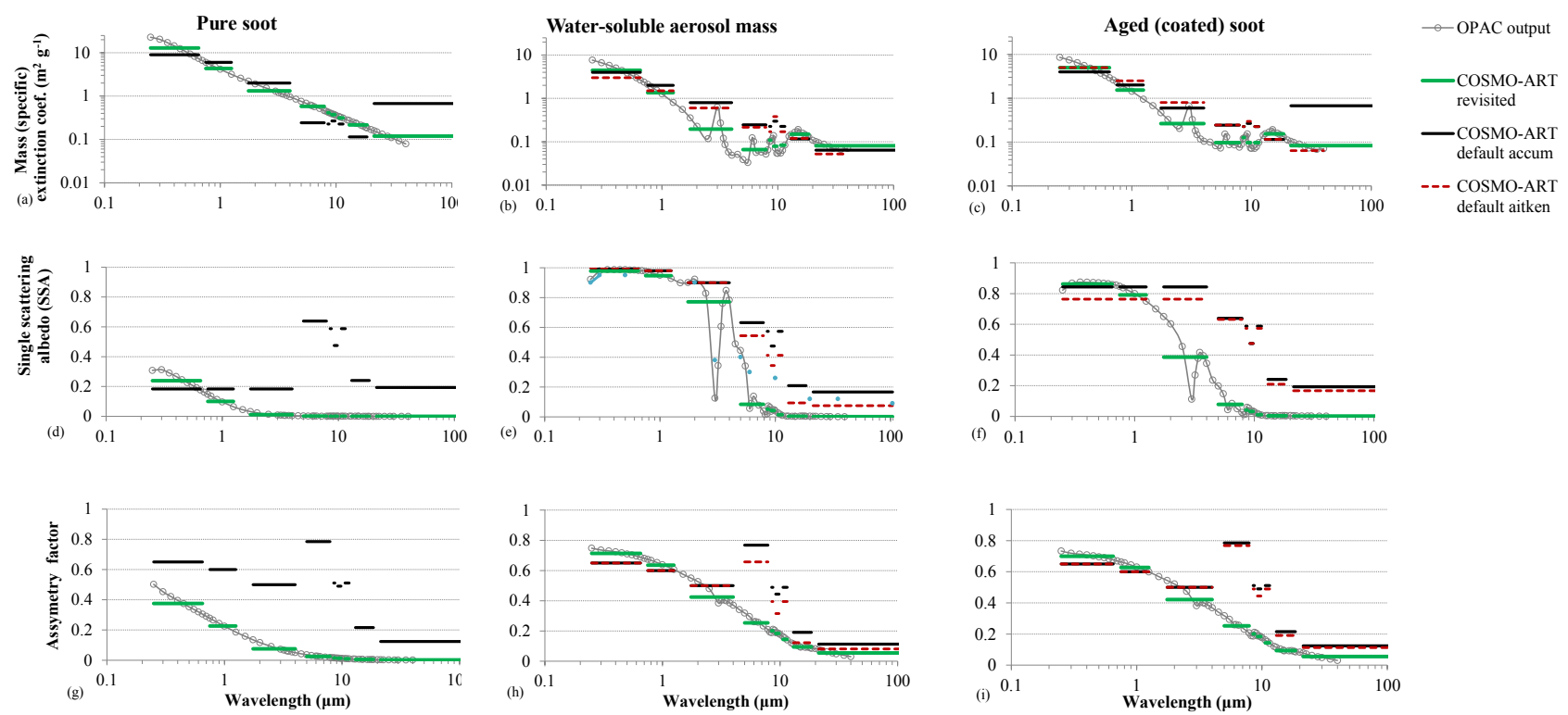

Figure 3. Specific extinction coefficient (a-c), single scattering albedo (d-f) and asymmetry factor (g-i) per wavelength for different mixtures of submicron aerosol (pure soot, water-soluble mass and coated soot) from the COSMO-ART configuration described in Vogel et al. (2009; black and red lines for the accumulation and nucleation mode, respectively; soot is represented by a single mode), from the OPAC algorithm (grey lines), and from the OPAC values adjusted to the COSMO-ART bands (green lines).

(see black line in Fig. 1a and Table 4). In contrast, the results of case 2 are greatly improved (80 and $23 \%$, respectively, for morning and nighttime PPEA), showing realistic diurnal profiles during the winter period (under crisis), when the mean hourly concentrations of modeled and measured $\mathrm{PM}_{10}$ ranged from 20 (morning) to $100 \mathrm{~g} \mathrm{~m}^{-3}$ (night; Fig. 5a). Overall, the revised run shows improvements in the calculated PPEA values for more than the $70 \%$ of the number of the day and nighttime $\mathrm{PM}_{10}$ peaks during the intense smog period.

As is evident in Table 3, the most important effect of the incorporation of the emission revisions into the model runs is the improved representation of the mean $\mathrm{PM}_{1} \mathrm{OA}$ and $\mathrm{PM}_{1} \mathrm{BC}$ mass fractions. In particular, $r^{2}$ equals 0.73 and 0.53 for the two components, respectively, with both being statistically significant at the $99 \%$ c.l. The chemical composition of oil combustion (central heating) greatly differs; thus, the baseline run (chemical profiles suggested by the TNO, given in Sect. 2.3) fails to represent winters during the years under crisis. Similarly to $\mathrm{PM}_{10}$, the hourly peaks of both submicron species cannot be reproduced by the baseline run (Table 4). In case 2 , the mean nighttime peak value of $\mathrm{PM}_{1} \mathrm{OA}$ is predicted to be $69.1 \mu \mathrm{g} \mathrm{m}^{-3}$, which is close to the measured value of $85.1 \mathrm{~g} \mathrm{~m}^{-3}$, while the outputs from case 1 are unrealistically low $\left(19.6 \mathrm{\mu g} \mathrm{m}^{-3}\right)$. The PPEA values for both carbonaceous species are significantly lower for case 2, i.e., for the half of the number of $\mathrm{PM}_{1} \mathrm{OA}$ daytime peaks and for all $\mathrm{PM}_{1} \mathrm{BC}$ daytime peaks that occurred during the intense smog period.
The mean diurnal cycles of both carbonaceous species (Fig. $5 \mathrm{~b}$ and c) are reproduced by case $2\left(r_{\mathrm{OA}}=0.91, r_{\mathrm{BC}}=\right.$ 0.8 ), while case 1 is strongly biased, especially during daytime for $\mathrm{PM}_{1} \mathrm{BC}$ (about 5-fold overestimation) and nighttime for $\mathrm{PM}_{1} \mathrm{OA}$ (about 3-fold underestimation). The mean hourly evening peak of $\mathrm{PM}_{1} \mathrm{OA}$ in the observations was $74.4 \mu \mathrm{g} \mathrm{m}^{-3}$ at 23:00 UTC, captured by the revised run $\left(62.7 \mu \mathrm{g} \mathrm{m}^{-3}\right.$ at 22:00 UTC; hourly MB equals $-6.5 \mu \mathrm{g} \mathrm{m}^{-3}$ ). The respective findings for $\mathrm{PM}_{1} \mathrm{BC}$ are $9.3 \mu \mathrm{g} \mathrm{m}^{-3}$ at 21:00 UTC in the ob-

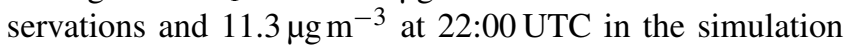
(hourly MB equals $3.5 \mu \mathrm{g} \mathrm{m}^{-3}$ ). The largest diurnal amplitude during a typical smog day was observed for organics for which the mean minimum (daytime) concentration was around 10 times lower than the mean maximum (nighttime), while a day-night difference by a factor of 7 was found for $\mathrm{PM}_{1} \mathrm{BC}$. This is related to the role of wood burning in each mass fraction, which is discussed further below.

The fact that the model biases in the RWB fraction of $\mathrm{BC}$ (case 2-case 3), OC/BC, BC/TC, TC/PM $10, \mathrm{OA} / \mathrm{PM}_{10}$ and $\mathrm{BC} / \mathrm{PM}_{10}$ are small further supports that the aerosol composition was accurately represented in case 2 . The mean values from predictions and observations at Thissio are presented in Table 5. All model findings are in agreement with observations. In particular, the mean fraction of RWB particles in the total mass of the predicted (measured) $\mathrm{PM}_{1} \mathrm{BC}$ was 42 (45) $\%$. This is a daily mean; i.e., the hourly fraction ranged from $25 \%$ (daytime) to $70 \%$ (nighttime) both in the measurements and the predictions (Fig. 5c). RWB smog was estimated to comprise up to $50 \%$ of $\mathrm{PM}_{10}$ concentrations during the intense smog period in Athens and to account for almost 


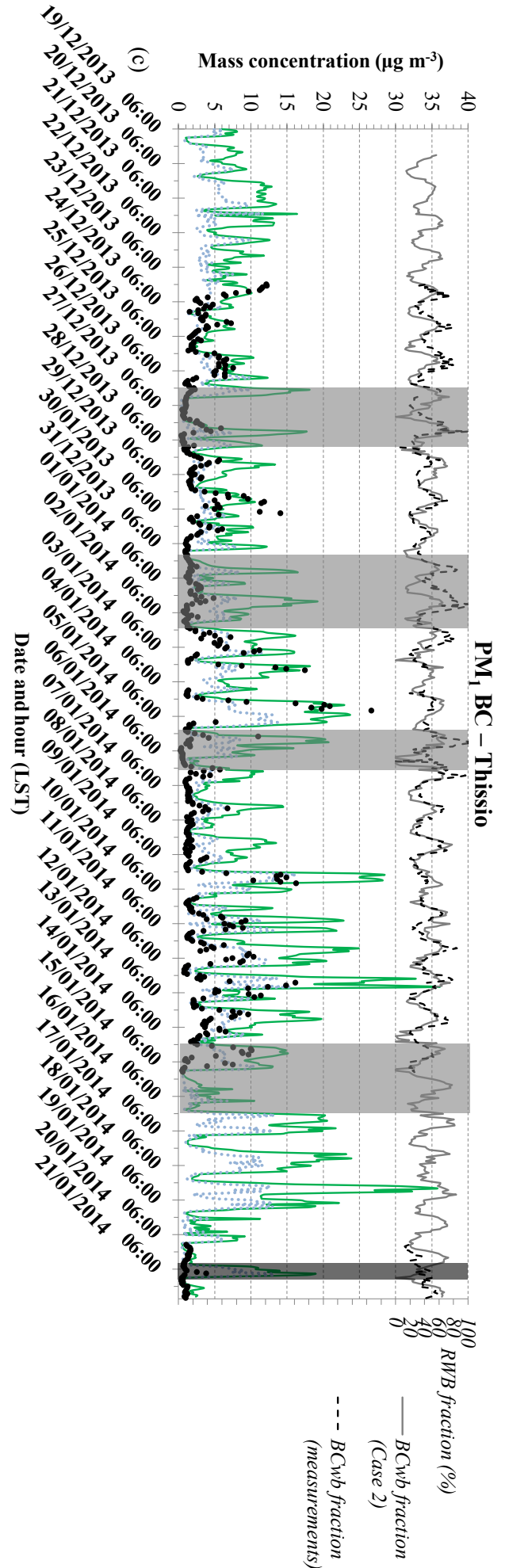

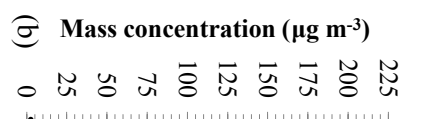
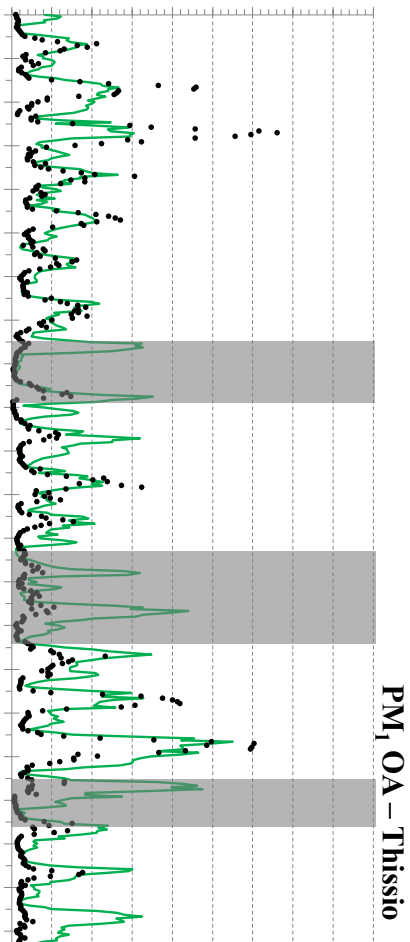

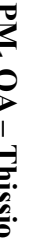
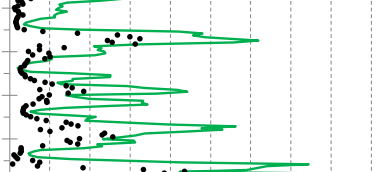

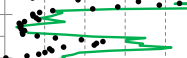

10.
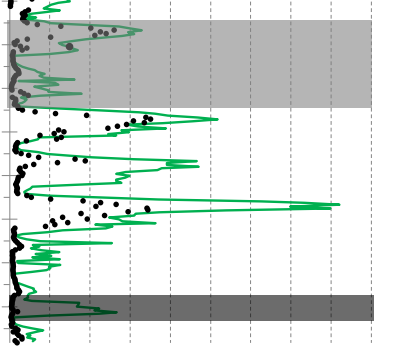

(2) Mass concentration $\left(\mu \mathrm{g} \mathrm{m}^{-3}\right)$

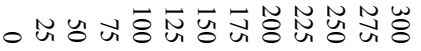

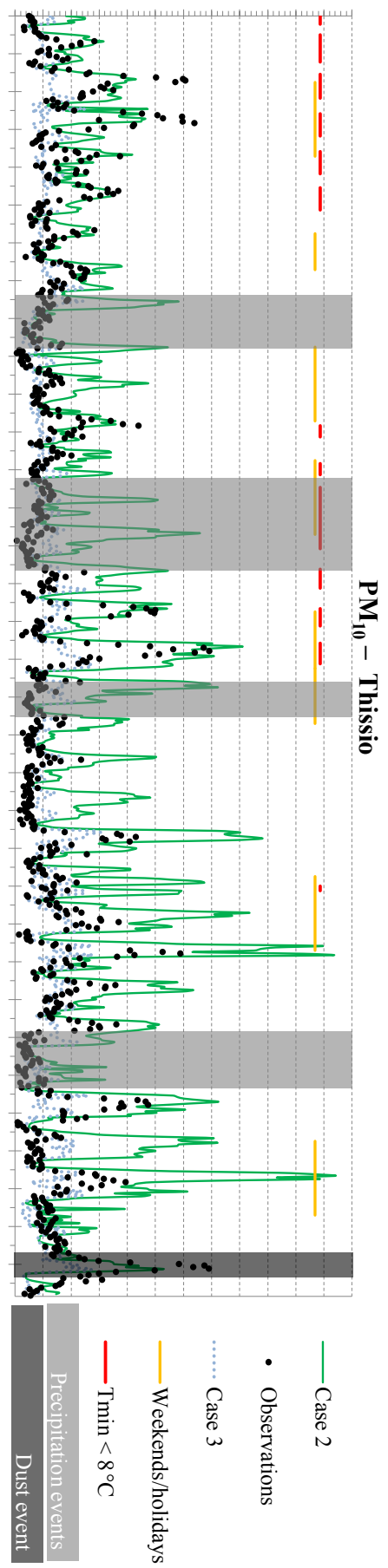

Figure 4. Time series of the hourly concentrations $\left(\mu \mathrm{g} \mathrm{m}^{-3}\right.$; left axis) of the (a) total $\mathrm{PM}_{10}$ mass, (b) submicron organic aerosol ( $\left.\mathrm{PM}_{1} \mathrm{OA}\right)$ and (c) submicron black carbon $\left(\mathrm{PM}_{1} \mathrm{BC}\right)$ from the COSMO-ART application (case 2, green line) and the measurements (black dots). The RWB fraction (\%) of black carbon $\left(\mathrm{BC}_{\mathrm{wb}}\right)$, as predicted (case 2) and observed, is shown by the grey and the black line, respectively (right axis). The cold nights (intense RWB smog episodes) and the weekends and holidays are shown by the red and yellow line, respectively. The shadowed areas indicate the rainy events (in light grey) and the dust event (in dark grey). 

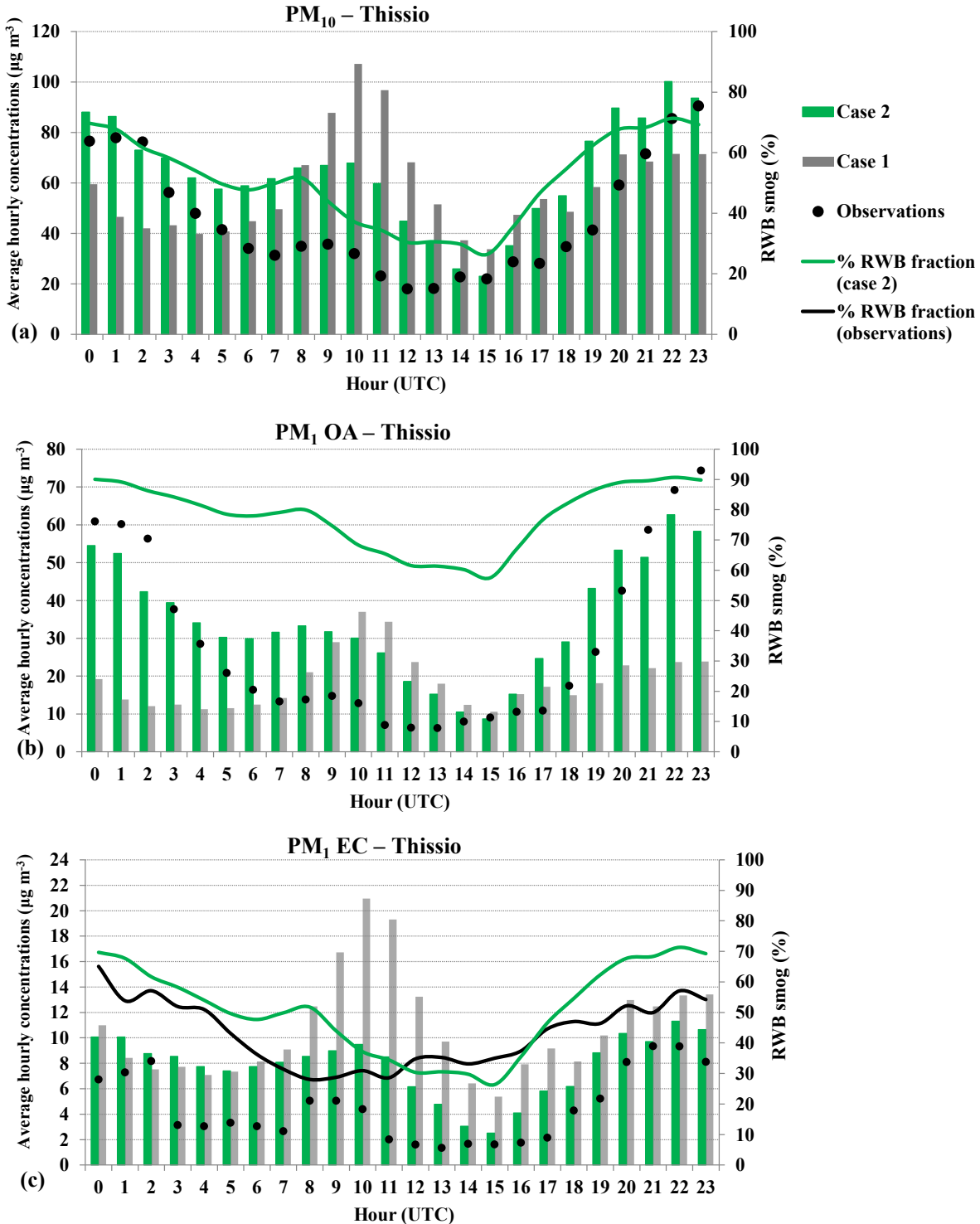

Figure 5. The mean daily cycle of mass concentrations $\left(\mu \mathrm{g} \mathrm{m}^{-3}\right.$ ) from measurements (black dots) and from model outputs (case 1 in grey columns and case 2 in green columns) and of RWB fractions (\%) from measurements (black line; only $\mathrm{BC}_{\mathrm{wb}}$ fraction is measured) and from model outputs (case 2 in green line) for (a) $\mathrm{PM}_{10}$, (b) $\mathrm{PM}_{1} \mathrm{OA}$ and (c) $\mathrm{PM}_{1} \mathrm{BC}$. All values refer to the Thissio site (Athens), and they correspond to the intense smog wintertime period.

$80 \%$ of $\mathrm{PM}_{1}$ organics (nighttime peak up to $90 \%$; Fig. 5 b). It is interesting to note that, in the case of organics, wood combustion continues to outweigh all other sources during the whole day (daytime value of more than $60 \%$ ). Thus, the aerosol chemical composition during the economic crisis is completely altered with respect to the chemical profile of wintertime aerosols beforehand.

The $\mathrm{OC} / \mathrm{BC}$ ratio calculated from the baseline run (1.1) is rather unrealistic, because it reflects typical urban environments, i.e., intense traffic, low biomass burning and limited regional contribution of aged aerosol. In contrast, both measurements (2.9) and revised predictions (2.8) are high- lighting the influence of biomass burning and high secondary formation rates of organics (Szidat et al., 2009; Pio et al., 2011; Gianini et al., 2013; Airuse, 2014). The carbonaceous aerosol dominates $\mathrm{PM}_{10}(62 \%)$ in wood burning conditions, of which more than $70 \%$ corresponds to organics. The latter makes up half of the total $\mathrm{PM}_{10}$ mass. Again, measurements and revised predictions are in agreement. The comparison with available measurements during increased wood burning in the Alpine area (Szidat et al., 2009) reveals similarities for the $\mathrm{EC} / \mathrm{TC}$ and $\mathrm{EC} / \mathrm{PM}_{10}$ ratios, while $\mathrm{OC} / \mathrm{BC}$ and $\mathrm{TC} / \mathrm{PM}_{10}$ showed somewhat higher values during those experiments (see Table 5). 

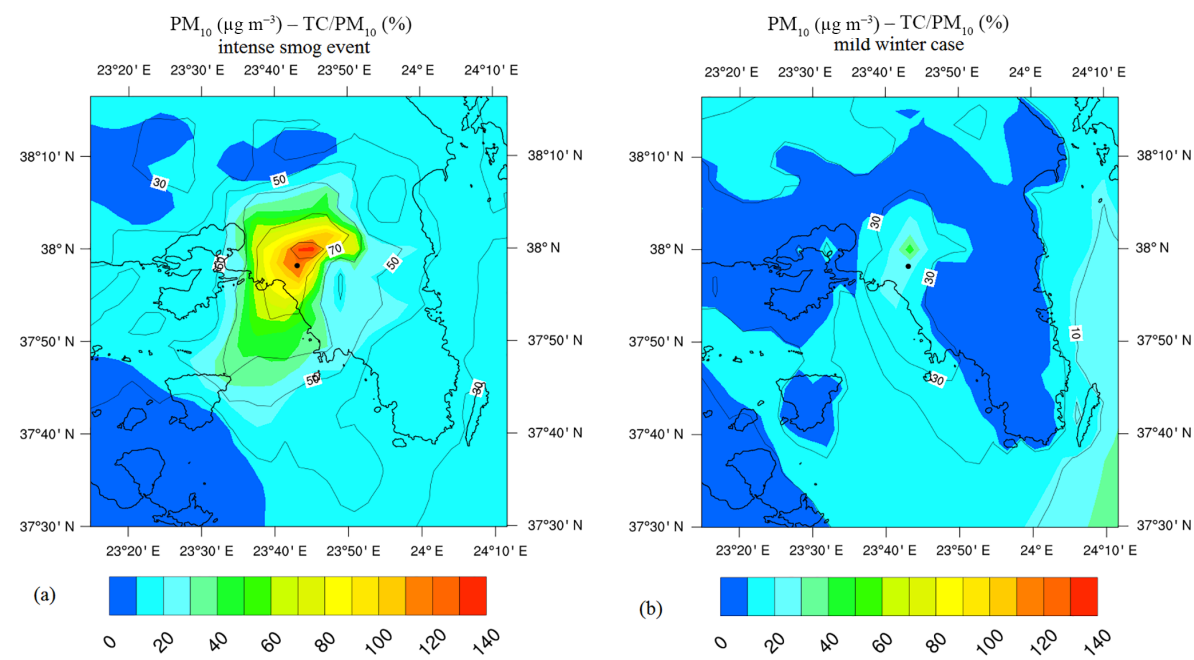

(b)
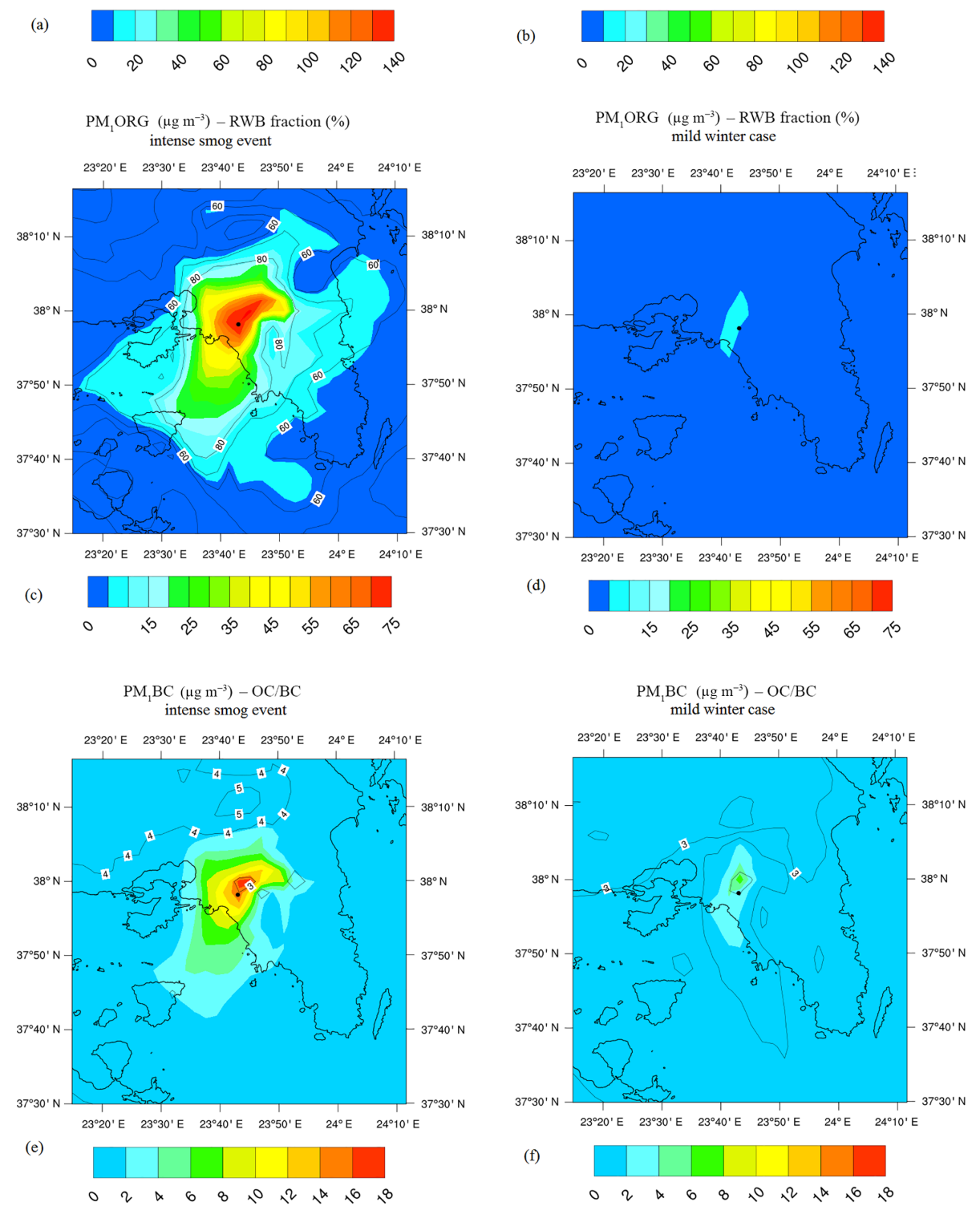

Figure 6. (a and b) Mean daily surface concentration $\left(\mu \mathrm{g} \mathrm{m}^{-3}\right.$ ) fields of $\mathrm{PM}_{10}$. Isolines represent the carbonaceous fraction $(\mathrm{OA}+\mathrm{BC})$ of $\mathrm{PM}_{10}(\%)$. (c and d) Mean daily surface concentration $\left(\mu \mathrm{g} \mathrm{m}^{-3}\right)$ fields of $\mathrm{PM}_{1} \mathrm{OA}$. Isolines represent the RWB fraction of $\mathrm{PM}_{1} \mathrm{OA}(\%)$. (e and f) Mean daily surface concentration $\left(\mu \mathrm{g} \mathrm{m}^{-3}\right)$ fields of $\mathrm{PM}_{1} \mathrm{BC}$. Isolines represent the $\mathrm{OC} / \mathrm{BC}$ ratio. $\mathrm{OC}$ is approximated as $\mathrm{OA}$ divided by 1.6, a ratio suggested by Turpin and Lim (2001) for urban areas. All maps cover the extended area of Athens (Thissio is marked with the black dot) and derive from model outputs that correspond to the intense smog event (case 1, left column) and to the mild winter case (case 3 , right column). 
Table 3. Averaged daily mean values and prediction skill metrics of the aerosol concentrations (and RWB mass fractions) against ground measurements (at Thissio) during the RWB smog period (19 December 2013-5 January 2014) in Athens. Numbers in bold represent the calculated statistics, given by Eqs. (A1) and (A2). SD is the standard deviation.

\begin{tabular}{|c|c|c|c|c|c|c|c|c|c|c|}
\hline Component & Parameter & Observations & $\begin{array}{l}\text { Case } 1 \\
\text { (baseline) }\end{array}$ & $\begin{array}{l}\text { Mean } \\
\text { hourly bias }\end{array}$ & $r^{2}$ & $\begin{array}{l}\text { MANGE } \\
(\%)\end{array}$ & $\begin{array}{l}\text { Case } 2 \\
\text { (revised) }\end{array}$ & $\begin{array}{l}\text { Mean } \\
\text { hourly bias }\end{array}$ & $r^{2}$ & $\begin{array}{l}\text { MANGE } \\
(\%)\end{array}$ \\
\hline $\begin{array}{l}\mathrm{PM}_{10} \mu \mathrm{g} \mathrm{m}^{-3} \\
\text { (332 samples) }\end{array}$ & $\begin{array}{l}\text { Averaged daily mean } \\
\text { (smog period) } \\
\text { SD } \\
\text { RWB fraction }(\%)^{*}\end{array}$ & $\begin{array}{l}45.2 \\
33.1\end{array}$ & $\begin{array}{l}58.7 \\
28.8\end{array}$ & 15.0 & 0.24 & 95 & $\begin{array}{l}50.8 \\
51\end{array}$ & 19.3 & 0.66 & 83 \\
\hline $\begin{array}{l}\mathrm{PM}_{1} \mathrm{OA} \mu \mathrm{g} \mathrm{m}^{-3} \\
\text { (333 samples) }\end{array}$ & $\begin{array}{l}\text { Averaged daily mean } \\
\text { (smog period) } \\
\text { SD } \\
\text { RWB fraction }(\%)^{*}\end{array}$ & $\begin{array}{l}28.4 \\
30.9\end{array}$ & $\begin{array}{l}18.8 \\
8.6\end{array}$ & -8.2 & 0.39 & 65 & $\begin{array}{l}34.4 \\
22.4 \\
78\end{array}$ & 6.6 & 0.73 & 118 \\
\hline $\begin{array}{l}\mathrm{PM}_{1} \mathrm{BC} \mu \mathrm{g} \mathrm{m}^{-3} \\
\text { (212 samples) }\end{array}$ & $\begin{array}{l}\text { Averaged daily mean } \\
\text { (smog period) } \\
\text { SD } \\
\text { RWB fraction }(\%)^{*}\end{array}$ & $\begin{array}{l}4.6 \\
3.8 \\
45\end{array}$ & $\begin{array}{l}9.9 \\
6.7\end{array}$ & 5.2 & 0.47 & 236 & $\begin{array}{l}7.1 \\
4.7 \\
42\end{array}$ & 2.5 & 0.53 & 121 \\
\hline
\end{tabular}

* RWB fraction predictions are the outcome of case 2-case 3 differences. Measurements for the same fraction are only provided for BC.

Table 4. Mean daytime and nighttime maximum values and prediction skill metrics of the aerosol concentrations against ground measurements (at Thissio) during the RWB smog period (19 December 2013-5 January 2014) in Athens. Numbers in bold represent the calculated statistics, given by Eq. (A3).

\begin{tabular}{lllllll}
\hline Component & Time frame & Observations & $\begin{array}{l}\text { Case 1 } \\
\text { (baseline) }\end{array}$ & $\begin{array}{l}\text { PPEA } \\
(\%)\end{array}$ & $\begin{array}{l}\text { Case 2 } \\
\text { (revised) }\end{array}$ & $\begin{array}{l}\text { PPEA } \\
(\%)\end{array}$ \\
\hline $\mathrm{PM}_{10} \mu \mathrm{g} \mathrm{m}^{-3}$ & daytime & 47.8 & 115.5 & $\mathbf{1 7 3}$ & 78.1 & $\mathbf{8 0}$ \\
$(332$ samples) & nighttime & 103.6 & 80.9 & $\mathbf{- 8}$ & 110.1 & $\mathbf{2 3}$ \\
$\mathrm{PM}_{1}{\mathrm{OA} \mu \mathrm{g} \mathrm{m}^{-3}}^{-3}$ & daytime & 23.5 & 23.9 & $\mathbf{1 1 9}$ & 39.3 & $\mathbf{1 0 3}$ \\
$(333$ samples $)$ & nighttime & 85.1 & 19.6 & $\mathbf{- 5 8}$ & 69.1 & $\mathbf{9}$ \\
$\mathrm{PM}_{1} \mathrm{BC}_{\mu \mathrm{g} \mathrm{m}}{ }^{-3}$ & daytime & 14 & 27 & $\mathbf{5 9 0}$ & 15 & $\mathbf{2 5 8}$ \\
$(212$ samples $)$ & nighttime & 5.2 & 12.6 & $\mathbf{6 3}$ & 11.3 & $\mathbf{3 8}$ \\
\hline
\end{tabular}

Table 5. Averaged daily means of selected aerosol mass fractions against ground measurements at Thissio (Athens) during the RWB smog period (19 December 2013-5 January 2014) and at Swiss Alpine areas (winter 2005; Szidat et al., 2009). Organic aerosol (OA) predictions are divided by 1.6 (Turpin and Lim, 2001) to extract the carbon mass (OC) used for the calculation of the $\mathrm{OC} / \mathrm{BC}$ ratio.

\begin{tabular}{llll}
\hline Component & $\begin{array}{l}\text { Observations } \\
\text { Athens/Alpine area }\end{array}$ & $\begin{array}{l}\text { Case 1 } \\
\text { (baseline) }\end{array}$ & $\begin{array}{l}\text { Case 2 } \\
\text { (revised) }\end{array}$ \\
\hline OC/BC & $2.9 / 3.7$ & 1.1 & 2.8 \\
$\mathrm{BC} / \mathrm{TC}$ & $0.28 / 0.23$ & 0.47 & 0.27 \\
$\mathrm{TC} / \mathrm{PM}_{10}$ & $0.62 / 0.89$ & 0.48 & 0.61 \\
$\mathrm{OA} / \mathrm{PM}_{10}$ & $0.50 /-$ & 0.32 & 0.51 \\
$\mathrm{BC} / \mathrm{PM}_{10}$ & $0.11 / 0.10$ & 0.17 & 0.11 \\
\hline
\end{tabular}

Overall, the exploitation of specialized, systematic measurements of $\mathrm{BC}_{\mathrm{wb}}$ has been crucial for updating the conventional TNO-MACC_II emission database and is a necessary step to accurately reproduce the aerosol pollution in Athens during the financial crisis. The revised temporal cy- cles and chemical profiles of the emissions from residential combustion significantly improved aerosol predictions, especially during peak hours (daytime for $\mathrm{PM}_{10}$ and $\mathrm{PM}_{1} \mathrm{BC}$ and nighttime for $\mathrm{PM}_{1} \mathrm{OA}$ ). Outliers (unrealistically high model values) occurred mainly during weekends with high nighttime temperatures outside the intense smog period (e.g., 12 and 18 January, see Fig. 4), which is further discussed in Sect. 3.1.3.

\subsubsection{Representative spatial aerosol fields}

Figure 6 depicts the spatial distribution of the daily mean surface aerosol concentrations $\left(\mathrm{PM}_{10}, \mathrm{PM}_{1} \mathrm{OA}\right.$ and $\left.\mathrm{PM}_{1} \mathrm{BC}\right)$ and corresponding fractions $\left(\mathrm{TC} / \mathrm{PM}_{10}, \mathrm{RWB}\right.$ and $\left.\mathrm{OC} / \mathrm{EC}\right)$ over the greater Athens area during the selected smog (left column) and mild (right column) event.

As seen, $\mathrm{PM}_{10}$ levels during these two events differ by more than a factor of 2 (contours in Fig. 6a and b), with concentrations during the smog event reaching $140 \mu \mathrm{g} \mathrm{m}^{-3}$ within the urban core, exceeding the national alarm value for emission measures $\left(100 \mathrm{\mu g} \mathrm{m}^{-3}\right.$; Joint Ministerial Decision by FEK 3272B/23-12-2013) and being above the stan- 
dard daily EU limit $\left(50 \mu \mathrm{g} \mathrm{m}^{-3}\right)$ over the entire Athens basin. Concentrations during the mild day reach up to $60 \mu \mathrm{g} \mathrm{m}^{-3}$, again exceeding the daily EU limit in the city center, which demonstrates the impact of RWB on air pollution throughout the entire winter period. This is related not only to the triggered accumulation of pollution due to the meteorology and topography of Athens, but also to the secondary organic aerosol formation due to RWB. Indeed, the largest fraction of $\mathrm{PM}_{10}$ during the smog event is composed of carbonaceous matter (TC up to $80 \%$, isolines in Fig. 6a), of which $80 \%$ is organic. This is even more clear in Fig. 5c, where organics are elevated over the entire basin during the smog event (up to $75 \mu \mathrm{g} \mathrm{m}^{-3}$ ) and the RWB fraction constitutes between $60 \%$ (city outskirts) and $80 \%$ (city center) of $\mathrm{PM}_{1} \mathrm{OA}$. During the mild period, in contrast, the air pollution is mainly composed of the rest of the aerosol species (sulfates, ammonium, nitrates, rest; isolines in Fig. 6b).

$\mathrm{PM}_{1} \mathrm{BC}$ concentration values reach very high levels under the RWB influence over the entire basin (daily values from 10 to $18 \mu \mathrm{g} \mathrm{m}^{-3}$; Fig. 6e), of which $60 \%$ corresponds to $\mathrm{BC}_{\mathrm{wb}}$ (not shown). In contrast, $\mathrm{PM}_{1} \mathrm{BC}$ is found below $8 \mu \mathrm{g} \mathrm{m}^{-3}$ during the mild day (Fig. 6f). The surface gradient of the $\mathrm{OC} / \mathrm{BC}$ ratio is very smooth - i.e., the effect of RWB on organic production and formation is regional and independent of the local peaks. This pattern seems to be stable in time, i.e., the high $\mathrm{OC} / \mathrm{BC}$ value (over 2.5) during the smog episode is close to the mean value during the extended smog period (Tables 3 and 5). Values around unity are found over the urban core - under typical heating and traffic-induced conditions (isolines in Fig. 6f).

Overall, the aerosol levels at Thissio (all three RWBaffected components) can be considered representative of an extended urban area around the city center. The peaks observed at the urban core, as revealed from this model application, are somewhat displaced from the exact location of the site. This finding is in line with the characterization provided by Gratsea et al. (2016), who used CO measurements from several sites (NAPM regulatory monitoring network of Athens) to characterize Thissio as an urban background site - not intensively affected by local traffic and representative of the average background pollution conditions in Athens.

In order to further support the representativeness of this site in a more quantitative way, we calculated the mean, minimum and maximum values of a greater urban area $\left(118 \mathrm{~km}^{2}\right.$, 15 cells; SW corner: $37.94,23.67^{\circ}$ ) and compared them to the model results at the grid point of Thissio. Indeed, the temporal mean (19 December-22 January 2014) point values of $\mathrm{PM}_{1} \mathrm{BC}, \mathrm{PM}_{1} \mathrm{OA}$ and $\mathrm{PM}_{10}\left(8.4,39.0,69.2 \mu \mathrm{g} \mathrm{m}^{-3}\right)$ are very close to the spatio-temporal averages over the extended urban domain $\left(7.4,37.8\right.$ and $64.9 \mu \mathrm{g} \mathrm{m}^{-3}$, respectively; difference on the order of 3-7\%). Furthermore, the hourly point values neither exceed the area peaks nor fall below the minimum values; instead, they correspond to 66-68\% of the maximum hourly concentrations found in the selected area. Lastly, the linear correlation among the site and the mean domain values

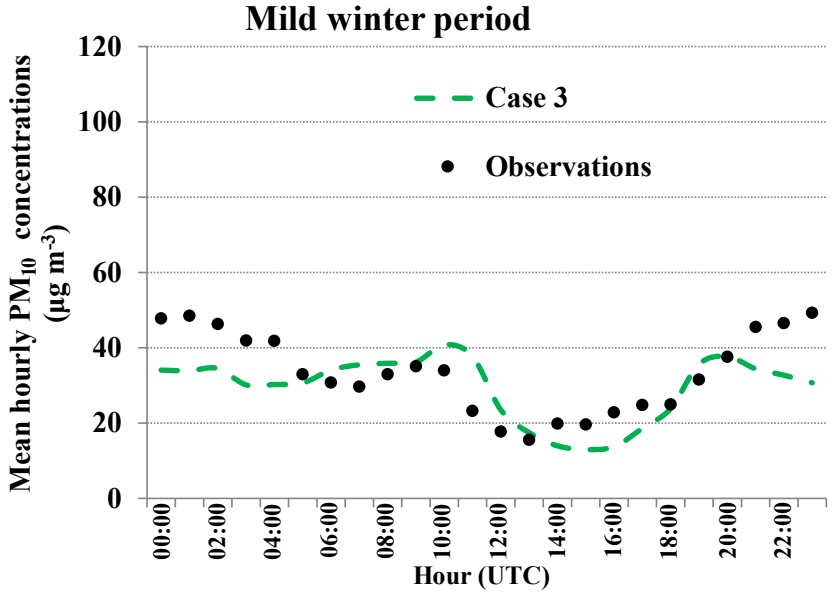

Figure 7. The mean daily cycle of $\mathrm{PM}_{10}$ concentrations during the mild winter period from the observations (black dots) and model predictions by case 3 (green line). All data refer to the Thissio site (Athens).

for all aerosol components is high $\left(r^{2}\right.$ above $\left.0.73, N=817\right)$ and close to the $1: 1$ line (slopes from 1.03 to 1.11 and intercepts below 0.8 ) for these three species.

\subsubsection{Heating demand and model bias}

As already pointed out in Sect. 3.1.1, aerosol concentrations were occasionally overestimated during mild winter weekends (concurrent green spikes and orange lines in Fig. 4a). In order to examine whether this is valid for the whole mild period (5-22 January 2014), the respective mean $\mathrm{PM}_{10}$ levels $\left(T_{\min }>8-9{ }^{\circ} \mathrm{C}\right)$ were compared with the daily cycle predicted from case 3 (Fig. 7). This run is indeed realistic; i.e., the actual wood burning during mild winter conditions in Greece is overestimated when using the TNOMACC_II emission rates to simulate such atmospheric conditions (green line from 5 January and onwards; Fig. 4a). Thus, we attempted to estimate a relation between mass concentrations and model bias with temperature conditions. This was performed by introducing the heating energy demand (HD) term, namely the energy needed to heat a home located in Athens. It is defined as the degrees below the base temperature, which is here chosen as $15.5^{\circ} \mathrm{C}$ (Carbon Trust, 2006).

Indeed, the observed hourly concentration levels of submicron aerosol in the city center of Athens during wintertime tend to increase with decreasing temperature (black dots in Fig. 8), and $\mathrm{PM}_{1} \mathrm{OA}$ nighttime spikes are above $100 \mu \mathrm{g} \mathrm{m}^{-3}$ only when air temperature falls below $8-9^{\circ} \mathrm{C}$. The explanation is two-fold: during cold weather conditions, firstly, the need for heating increases and thus all means of heating including fireplaces and woodstoves are expected to maximize, resulting in high RWB emissions. Secondly, the same conditions coincide with reduced vertical mixing over Athens, with mixing layer heights varying between 200 and $400 \mathrm{~m}$, 


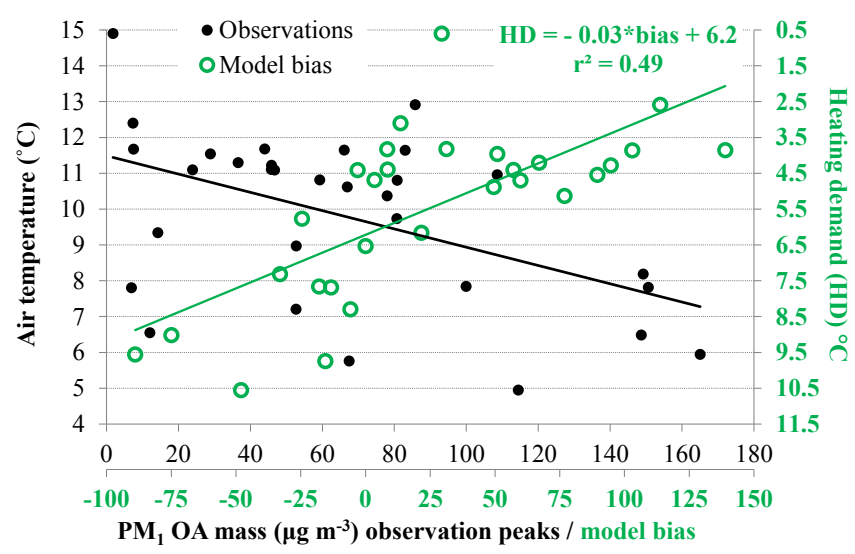

Figure 8. The linear correlation between air temperature $\left({ }^{\circ} \mathrm{C}\right)$ and submicron organic aerosol concentration peaks $\left(\mathrm{PM}_{1} \mathrm{OA}\right.$ in $\mu \mathrm{g} \mathrm{m}^{-3}$, in black) and between the heating demand ( $\mathrm{HD}$, in $\left.{ }^{\circ} \mathrm{C}\right)$ and the model bias (for $\mathrm{PM}_{1} \mathrm{OA}$ in $\mu \mathrm{g} \mathrm{m}^{-3}$, in green). All data refer to the Thissio site (Athens).

which support the accumulation of air pollutants near the surface.

In order to identify the link between the model discrepancies and the actual space heating demand in Athens, the trend of the nighttime $\mathrm{PM}_{1} \mathrm{OA}$ model bias and the daily maximum heating demand (at the $T_{\min }$ of each day) was examined for the whole period (green dots in Fig. 8), excluding the rainy events. There is a significant correlation between the two parameters $\left(r^{2}=0.49\right)$, which shows that when the demand for heating decreases (i.e., at milder temperatures) the model tends to overestimate the aerosol concentrations. In particular, all model biases from $+25 \mu \mathrm{g} \mathrm{m}^{-3}$ and above occur only when the HD is low $\left(<6.5^{\circ} \mathrm{C}\right)$, i.e., when nighttime air temperature is above $9^{\circ} \mathrm{C}$. Inversely, during the cold days $\left(T_{\min }\right.$ below $\left.8^{\circ} \mathrm{C}\right)$ the $\mathrm{HD}$ is increased $\left(>7.5^{\circ} \mathrm{C}\right)$, and consequently no model overestimation occurs.

This analysis shows the limitations of using average temporal profiles for the calculation of emissions from residential heating to feed model simulations when the study period is extended and not focused on specific wintertime smog episodes. Evidently, the TNO-MACC_II residential wood combustion aerosol emission rates (using the updated temporal cycles proposed by the current study) are "ideal" under typical winter conditions that lead to moderate or increased residential heating demand and during stay-at-home days (e.g., weekdays, holidays). It should be noted that this study has focused on the crisis period; i.e., a switch occurs in the domestic heating fuel from heating oil to wood. Thus, the TNO-MACC_II emissions from the residential combustion sector should be handled with caution when the period of interest has different characteristics with respect to space heating conditions (e.g., pre-crisis years).

\subsection{Impact of RWB smog on radiation and feedbacks on atmospheric composition}

The effect of aerosols on total surface radiation during the simulated winter period was approximated by comparing case 2 with case 4 . This is presented as a monthly mean in Fig. 9a. As expected, the effect of total aerosol over the extended area of Athens is negative; i.e., the scattering of radiation by particles (organics, sulfates, etc.) outweighs absorption by black carbon and the reflection of shortwave radiation $\left(-1.9 \mathrm{~W} \mathrm{~m}^{-2}\right)$ outweighs the enhanced trapping of longwave radiation $\left(+0.5 \mathrm{~W} \mathrm{~m}^{-2}\right)$. Nevertheless, the mean monthly effect does not exceed $-1.4 \mathrm{~W} \mathrm{~m}^{-2}$ at the urban core, and by comparing cases 2,3 and 4 it is found that only $30 \%$ of this effect corresponds to particles from RWB. This means that the mean direct radiative effect due to RWB at the surface does not exceed the value of $-0.4 \mathrm{~W} \mathrm{~m}^{-2}$. This small negative effect of particles on radiation is explained by the fact that most of the RWB emissions occur during nighttime when only the long-range terrestrial radiation is reflected (positive DRE values up to $+0.4 \mathrm{~W} \mathrm{~m}^{-2}$ ). The role of timing on the aerosol radiative impacts has already been analyzed for a dust storm over the eastern Mediterranean (Rémy et al., 2015), when an important positive feedback between aerosol and meteorology occurred during nighttime. In addition, the residual plume during the next day is weakened due to removal and dispersion processes. Indicatively, the nighttime $\mathrm{PM}_{10}$ mean during the RWB smog episode (4-5 January 2014) reached $145 \mu \mathrm{g} \mathrm{m}^{-3}$, while the daytime mean was $98 \mu \mathrm{g} \mathrm{m}^{-3}$, of which $50 \%$ corresponded to RWB particles. By further subtracting the absorbing $\mathrm{BC}$ aerosols $\left(14 \mu \mathrm{g} \mathrm{m}^{-3}\right)$ from the RWB mean $\mathrm{PM}_{10}$ concentration value, it is calculated that only $35 \mu \mathrm{g} \mathrm{m}^{-3}$ corresponded to aerosols scattering in the shortwave during the peak smog event of the studied period, causing a DRE of $-0.8 \mathrm{~W} \mathrm{~m}^{-2}$ at the urban core (Fig. 9b).

The related feedback on atmospheric composition is very small, consistent with the low DRE value. Specifically, the feedback on the mean monthly concentration values (case 2case 4), for all aerosol species, is found to be positive and in the range of $0.4-0.6 \mu \mathrm{g} \mathrm{m}^{-3}$, which represents 1 and $3 \%$, respectively, of the total $\mathrm{PM}_{1} \mathrm{OA}$ or $\mathrm{PM}_{1} \mathrm{BC}$ mean monthly concentration found at the urban core. This slight increase in the concentration of aerosol species due to the aerosolradiation interaction is associated with an almost $10 \mathrm{~m}$ lower mean PBL height in case 2 compared to case 4 , in accordance with the respective findings in Forkel et al. (2012).

Finally, we performed a run using the optical properties of aerosol from Vogel et al. (2009), which were compared to cases 2 and 3. The differences in the DRE were found to be negligible (not shown). This is explained by the fact that most of the imposed changes in the aerosol properties (see Sect. 2.4) correspond to the pure soot mode. Nevertheless, the atmospheric particles over an urban area correspond mainly to aged soot (coated with soluble material) - 

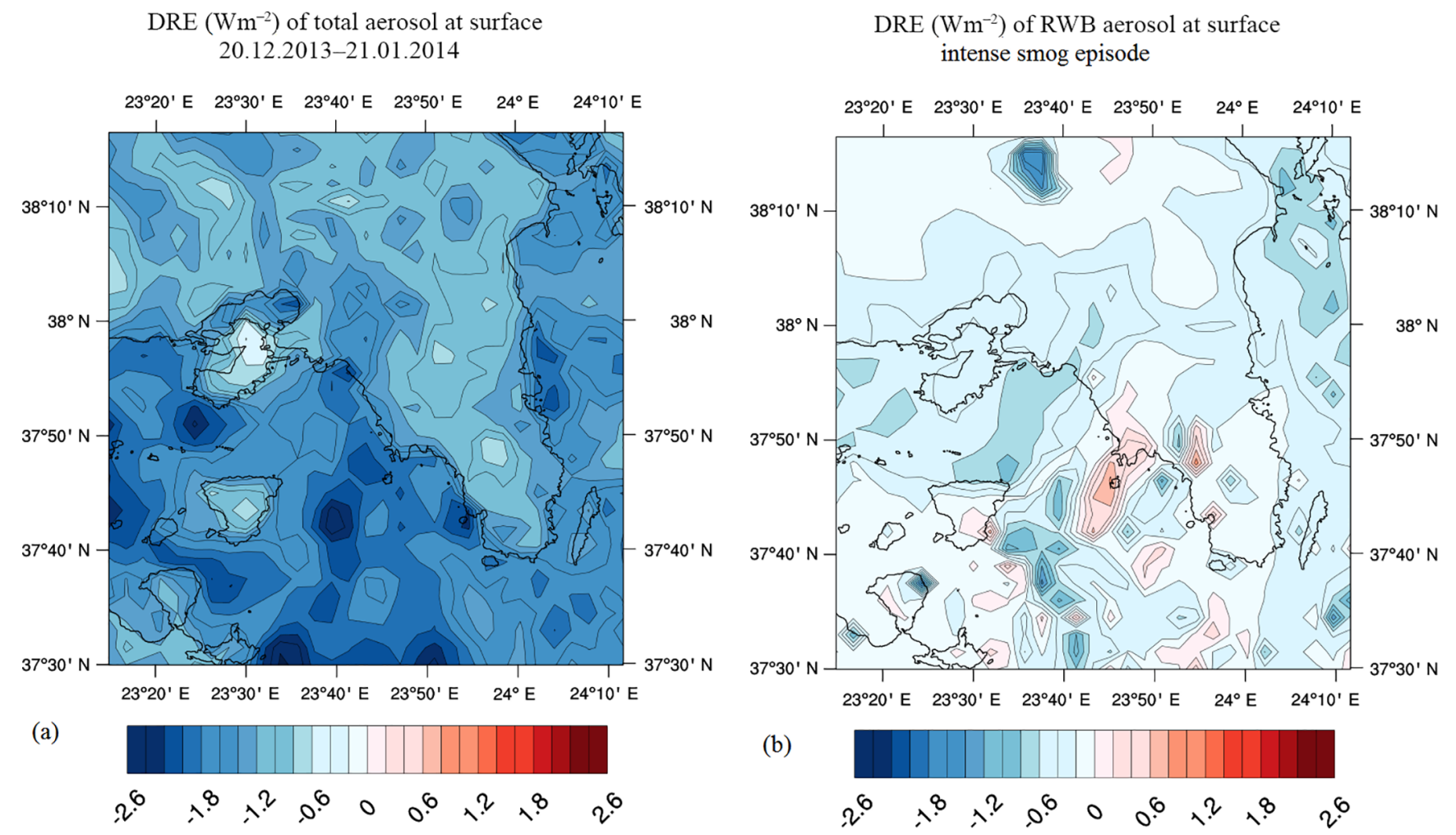

Figure 9. The spatial distribution of the direct radiative effect $\left(\mathrm{Wm}^{-2}\right)$ of the aerosol load at the ground level, over the extended area of Athens, during (a) a winter month (20 December 2013-21 January 2014), taking into account the total aerosol load (mean monthly difference between case 2 and case 4); and (b) the RWB smog episode (4-5 January 2014), isolating the RWB aerosol load (mean daily difference between case 2 and case 3 ).

an aerosol mode whose properties in Vogel et al. (2009) differ from the ones in this study on the longwave part of the spectrum (see Fig. 3). However, the wavelength range above $2 \mu \mathrm{m}$ is not significantly affected by particles, as already explained. Conclusively, the shortwave scattering in both runs did not change significantly, leading to similar findings for DRE.

\section{Conclusions}

This study examines the air quality impacts of increasing use of wood burning for domestic heating, through a modelbased analysis of a characteristic case study in Athens, Greece, as an immediate consequence of the ongoing economic crisis. A cold period $\left(T_{\min }<10^{\circ} \mathrm{C}\right)$ with intense RWB smog conditions (nighttime $\mathrm{PM}_{10}$ hourly peaks from 75 to $173 \mu \mathrm{g} \mathrm{m}^{-3}$ ) was selected for the characterization of the aerosol levels and chemistry over the urban area. Two representative events were distinguished for an analysis of the spatial representation of the smog plume during a cold $\left(T_{\min }=8.2^{\circ} \mathrm{C}\right)$ and a mild $\left(T_{\min }=10.6^{\circ} \mathrm{C}\right)$ winter day with high and low nighttime peaks at Thissio $\left(\mathrm{PM}_{10}\right.$ at 173 and $59 \mathrm{\mu g} \mathrm{m}^{-3}$, respectively).
The daily mean $\mathrm{PM}_{10}$ concentration at Thissio during the RWB smog period derived from the measurements and the model (in parentheses) was $45.2(50.8) \mu \mathrm{g} \mathrm{m}^{-3}$. The respective values for $\mathrm{PM}_{1} \mathrm{OA}$ and $\mathrm{BC}$ were 28.4 (34.4) and 4.6 (7.1) $\mu \mathrm{g} \mathrm{m}^{-3}$. $\mathrm{PM}_{10}$ levels during the smog (cold) event exceeded the EU daily limit for the entire Athens basin (model outputs). This finding is primarily related to RWB particles, which comprised $50 \%$ of the total $\mathrm{PM}_{10}$ levels. The impact of RWB on air pollution persisted throughout winter; i.e., exceedances also occurred during the mild days but were confined to the urban core.

According to a spatio-temporal analysis of the current model results, the concentration values at Thissio are representative of an extended urban area, i.e., of the average pollution conditions in Athens. The day-night differences in the concentrations of different aerosol components were found to be very large (5-, 10- and 7-fold for $\mathrm{PM}_{10}, \mathrm{PM}_{1} \mathrm{OA}$ and $\mathrm{PM}_{1} \mathrm{BC}$, respectively) because of the intense RWB activity and the changes in PBL under cold nighttime conditions. In particular, the observed (simulated) peaks in $\mathrm{PM}_{10}$, $\mathrm{PM}_{1} \mathrm{OA}$ and $\mathrm{PM}_{1} \mathrm{BC}$ between 21:00 and 23:00 UTC were on average $90.5(100.2) \mu \mathrm{g} \mathrm{m}^{-3}, 74.4(62.7) \mu \mathrm{g} \mathrm{m}^{-3}$ and 9.3 (11.3) $\mu \mathrm{g} \mathrm{m}^{-3}$, respectively. These values correspond to almost $70 \%$ of the maximum hourly concentrations over an ex- 
tended urban area, further supporting that Thissio represents urban background air pollution conditions over the Athens basin.

The carbonaceous component $(\mathrm{OA}+\mathrm{BC})$ of $\mathrm{PM}_{10}$ in Athens during the smog period reached 62 (61) \%, half of which is attributed to the organic matter. This means that RWB completely alters the chemical profile of $\mathrm{PM}_{10}$ over Athens during wintertime, as the RWB smog fraction of $\mathrm{PM}_{1} \mathrm{OA}$ (according to the simulation) ranged from $60 \%$ during daytime to $90 \%$ during nighttime, and $\mathrm{BC}_{\mathrm{wb}}$ accounted for $25 \%$ during daytime to $70 \%$ during nighttime of $\mathrm{BC}_{\text {tot }}$ (according to both the measurements and simulation). The mean $\mathrm{OC} / \mathrm{BC}$ ratio at Thissio from measurements (model outputs) was 2.9 (2.8), which is characteristic of the RWB influence and secondary formation of organics. Again, this value is representative of the entire Athens basin during wintertime, according to the spatio-temporal analysis of the model outputs.

Interestingly, the earth radiative budget was on average not altered significantly despite these high aerosol loads, due to the compensation of longwave and shortwave effects and the fact that RWB peaks occur in the nighttime hours, resulting in a weak residual plume on the next day. Overall, the mean direct radiative effect of wintertime RWB smog was estimated as low as $-0.4 \mathrm{~W} \mathrm{~m}^{-2}$, with a subsequent feedback on the concentration of each of the simulated aerosol species less than $+0.6 \mu \mathrm{g} \mathrm{m}^{-3}$.
For the model to properly capture the wintertime aerosol values observed in Athens, a revision of the residential combustion emission sector was necessary. This was facilitated via a unique, long-term dataset of a well-defined wood burning indicator $\left(\mathrm{BC}_{\mathrm{wb}}\right)$ obtained at Thissio station. In particular, the TNO-MACC_II RWB emissions for particulate matter were revised with respect to their temporal and chemical profiles. The coupling to a high-resolution emission inventory, with possible benefits to the special allocation of local emission sources (Gon et al., 2011; López-Aparicio et al., 2017), is a planned activity for the forthcoming atmospheric intra-urban simulations over Athens.

The updated model configuration was found to greatly improve the prediction of smog episodes during wintertime. Thus, human health implications, as well as policy making, when the fireplaces are in use to cope with high heating demand conditions $\left(\mathrm{HD}>7.5^{\circ} \mathrm{C}\right.$ ) can be satisfactorily estimated and planned with the aid of such a tool. For mild winter conditions $\left(T_{\min }>8-9{ }^{\circ} \mathrm{C}\right)$, a post-processing of model results according to the linear regression between $\mathrm{HD}$ and model bias can further improve the quality of the model system. Alternatively, an interactive treatment of RWB emissions, i.e., their online adjustment according to the actual temperature conditions of the simulation period, is proposed as a means to further enhance the reliability of operational forecasts of online-coupled atmospheric models.

Data availability. The underlying research data are available upon request from the corresponding authors (Eleni Athanasopoulou at eathana@noa.gr and Evangelos Gerasopoulos at egera@noa.gr). 


\section{Appendix A}

The mean absolute normalized gross error (MANGE) is calculated by Eq. (A1) and the correlation coefficient $(r)$ by Eq. (A2):

MANGE $=\frac{1}{N} \sum_{i=1}^{N} \frac{\left(E_{i}-O_{i}\right)}{O_{i}} 100 \%$,

$r=\left[\frac{\sum_{i=1}^{N}\left(E_{i}-\bar{E}\right)\left(O_{i}-\bar{O}\right)}{\sum_{i=1}^{N}\left(E_{i}-\bar{E}\right) \sum_{i=1}^{N}\left(O_{i}-\bar{O}\right)}\right]$,

where $E$ is the estimated (modeled) and $O$ is the observed value of each parameter, paired in space and time for each $i$ of $N$ data pairs; and $\bar{E}$ and $\bar{O}$ are the mean values of estimations and observations, respectively.

The paired peak estimation accuracy (PPEA) is calculated as below:

$\mathrm{PPEA}=\frac{1}{N} \sum_{i=1}^{N} \frac{\left(\mathrm{EM}_{i}-\mathrm{OM}_{i}\right)}{\mathrm{OM}_{i}} 100 \%$,

where EM is the estimated (modeled) and OM is the observed peak $1 \mathrm{~h}$ value of each parameter, paired in space and time for each $i$ of $N$ data pair. 
Competing interests. The authors declare that they have no conflict of interest.

Special issue statement. This article is part of the special issue "Coupled chemistry-meteorology modeling: status and relevance for numerical weather prediction, air quality and climate communities (SI of EuMetChem COST ES1004) (ACP/GMD inter-journal SI)". Part of this work was presented at the symposium on Coupled Chemistry-Meteorology/Climate Modelling, WMO Headquarters, Geneva, Switzerland, 23-25 February 2015.

Acknowledgements. This work has been financially supported by the project ACTRIS-2 and the project THESPIA of the action KRIPIS (GSRT). Project ACTRIS-2 Integrating Activities (IA) has received funding from the European Union's Horizon 2020 research and innovation programme (grant agreement No 654109). THESPIA was financed by Greece and the European Regional Development Fund of the EU in the frame of NSRF and the O.P. Competitiveness and Entrepreneurship and the Regional Operational Program of Attica. The computational time spent for this study was provided by the Greek Research and Technology Network (GRNET) in the National HPC facility - ARIS - under project ID AQ4ATH and AEClEM. We appreciate the German Weather Service (DWD) for providing access to their forecast data records. We acknowledge the NOA colleagues responsible for the operation of the aerosol site at Thissio (E. Liakakou, A. Bougiatioti, B. Psiloglou, M. Lianou, I. Stavroulas and L. Fourtziou), our communication with H. Denier van Der Gon (TNO) with respect to emissions and U. Schättler (DWD) for his continuous support in the configuration of the COSMO model.

Edited by: Alexander Baklanov

Reviewed by: two anonymous referees

\section{References}

Athanasopoulou, E., Vogel, H., Vogel, B., Tsimpidi, A. P., Pandis, S. N., Knote, C., and Fountoukis, C.: Modeling the meteorological and chemical effects of secondary organic aerosols during an EUCAARI campaign, Atmos. Chem. Phys., 13, 625-645, https://doi.org/10.5194/acp-13-625-2013, 2013.

Athanasopoulou, E., Rieger, D., Walter, C., Vogel, H., Karali, A., Hatzaki, M., Gerasopoulos, E., Vogel, B., Giannakopoulos, C., Gratsea, M., and Roussos, A.: Fire risk, atmospheric chemistry and radiative forcing assessment of wildfires in eastern Mediterranean, Atmos. Environ., 95, 113-125, https://doi.org/10.1016/j.atmosenv.2014.05.077, 2014.

Baldauf, M., Seifert, A., Förstner, J., Majewski, D., Raschendorfer, M., and Reinhardt, T.: Operational Convective-Scale Numerical Weather Prediction with the COSMO Model: Description and Sensitivities, Mon. Weather Rev., 139, 3887-3905, https://doi.org/10.1175/MWR-D-10-05013.1, 2011.

Bangert, M., Kottmeier, C., Vogel, B., and Vogel, H.: Regional scale effects of the aerosol cloud interaction simulated with an online coupled comprehensive chemistry model, Atmos.
Chem. Phys., 11, 4411-4423, https://doi.org/10.5194/acp-114411-2011, 2011.

Bangert, M., Nenes, A., Vogel, B., Vogel, H., Barahona, D., Karydis, V. A., Kumar, P., Kottmeier, C., and Blahak, U.: Saharan dust event impacts on cloud formation and radiation over Western Europe, Atmos. Chem. Phys., 12, 4045-4063, https://doi.org/10.5194/acp-12-4045-2012, 2012.

Bari, M. A.: Air Pollution in Residential Areas from Woodfired Heating, Aerosol Air Qual. Res., 11, 749-757, https://doi.org/10.4209/aaqr.2010.09.0079, 2011.

Bäumer, D., Lohmann, U., Lesins, G., Li, J., and Croft, B.: Parameterizing the optical properties of carbonaceous aerosols in the Canadian Centre for Climate Modeling and Analysis Atmospheric General Circulation Model with impacts on global radiation and energy fluxes, J. Geophys. Res., 112, https://doi.org/10.1029/2006JD007319, 2007.

Bølling, A. K., Pagels, J., Yttri, K. E., Barregard, L., Sallsten, G., Schwarze, P. E., and Boman, C.: Health effects of residential wood smoke particles: the importance of combustion conditions and physicochemical particle properties, Part Fibre Toxicol., 29, https://doi.org/10.1186/1743-8977-6-29, 2009.

Bond, T. C., Doherty, S. J., Fahey, D. W., Forster, P. M., Berntsen, T., DeAngelo, B. J., Flanner, M. G., Ghan, S., Kärcher, B., Koch, D., Kinne, S., Kondo, Y., Quinn, P. K., Sarofim, M. C., Schultz, M. G., Schulz, M., Venkataraman, C., Zhang, H., Zhang, S., Bellouin, N., Guttikunda, S. K., Hopke, P. K., Jacobson, M. Z., Kaiser, J. W., Klimont, Z., Lohmann, U., Schwarz, J. P., Shindell, D., Storelvmo, T., Warren, S. G., and Zender, C. S.: Bounding the role of black carbon in the climate system: a scientific assessment, J. Geophys. Res.Atmos., 118, 5380-5552, https://doi.org/10.1002/jgrd.50171, 2013.

Borrego, C., Valente, J., Carvalho, A., Sá, E., Lopes, M., and Miranda, A. I.: Contribution of residential wood combustion to $\mathrm{PM}_{10}$ levels in Portugal, Atmos. Environ., 44, 642-651, https://doi.org/10.1016/j.atmosenv.2009.11.020, 2010.

Carbon Trust: Degree days for energy management - A practical introduction, Carbon Trust, 20, available at: http: //www.minus3.org/dokumenti/Final_Report_16_July_2009/ Appendix_3_-_Degree_Days_for_Energy_Management.pdf, 2006.

Denier van der Gon, H., Visschedijk, A., van der Brugh, H., and Droege, R.: A high resolution European emission data base for the year 2005, a contribution to UBA- Projekt PAREST: Particle Reduction Strategies, Utrecht, TNO-report TNO-034-UT-201001895 RPTML, 2010.

Denier van der Gon, H., Hendriks, C., Kuenen, J., Segers, A., and Visschedijk, A.: Description of current temporal emission patterns and sensitivity of predicted AQ for temporal emission patterns, Utrecht, TNO-report EU FP7 MACC deliverable report D_D-EMIS_1.3, 2011.

Denier van der Gon, H. A. C., Bergström, R., Fountoukis, C., Johansson, C., Pandis, S. N., Simpson, D., and Visschedijk, A. J. H.: Particulate emissions from residential wood combustion in Europe - revised estimates and an evaluation, Atmos. Chem. Phys., 15, 6503-6519, https://doi.org/10.5194/acp15-6503-2015, 2015.

EEA European Environment Agency: Emissions of primary particles and secondary particulate matter precursors, Indicator code 
CSI 003, available at: http://www.eea.europa.eu/data-and-maps/ indicators/ds_resolveuid/781d346e34436a4aacf75c63e7288078 (last access: 25 August 2017), 2011.

EEA European Environmental Agency: Air Quality in Europe 2016 Report, Publications Office of the European Union, EEA Report, No 28/2016, https://www.eea.europa.eu/publications/ air-quality-in-europe-2016/at_download/file, 2016.

Emmons, L. K., Walters, S., Hess, P. G., Lamarque, J.-F., Pfister, G. G., Fillmore, D., Granier, C., Guenther, A., Kinnison, D., Laepple, T., Orlando, J., Tie, X., Tyndall, G., Wiedinmyer, C., Baughcum, S. L., and Kloster, S.: Description and evaluation of the Model for Ozone and Related chemical Tracers, version 4 (MOZART-4), Geosci. Model Dev., 3, 43-67, https://doi.org/10.5194/gmd-3-43-2010, 2010.

Fameli, K.-M., and Assimakopoulos, V. D.: The new open Flexible Emission Inventory for Greece and the Greater Athens Area (FEI-GREGAA): account of pollutant sources and their importance from 2006 to 2012, Atmos. Environ., 137, 17-37, https://doi.org/10.1016/j.atmosenv.2016.04.004, 2016.

Forkel, R., Werhahn, J., Hansen, A. B., McKeen, S., Peckham, S., Grell, G., and Suppan, P.: Effect of aerosolradiation feedback on regional air quality - a case study with WRF/Chem, Atmos. Environ., 53, 202-211, https://doi.org/10.1016/j.atmosenv.2011.10.009, 2012.

Fountoukis, C. and Nenes, A.: ISORROPIA II: a computationally efficient thermodynamic equilibrium model for $\mathrm{K}^{+}-\mathrm{Ca}^{2+}$ $\mathrm{Mg}^{2+}-\mathrm{NH}_{4}^{+}-\mathrm{Na}^{+}-\mathrm{SO}_{4}^{2}--\mathrm{NO}_{3}^{-}-\mathrm{Cl}^{-}-\mathrm{H}_{2} \mathrm{O}$ aerosols, Atmos. Chem. Phys., 7, 4639-4659, https://doi.org/10.5194/acp-7-46392007, 2007.

Fountoukis, C., Megaritis, A. G., Skyllakou, K., Charalampidis, P. E., Pilinis, C., Denier van der Gon, H. A. C., Crippa, M., Canonaco, F., Mohr, C., Prévôt, A. S. H., Allan, J. D., Poulain, L., Petäjä, T., Tiitta, P., Carbone, S., Kiendler-Scharr, A., Nemitz, E., O'Dowd, C., Swietlicki, E., and Pandis, S. N.: Organic aerosol concentration and composition over Europe: insights from comparison of regional model predictions with aerosol mass spectrometer factor analysis, Atmos. Chem. Phys., 14, 9061-9076, https://doi.org/10.5194/acp-14-9061-2014, 2014.

Fourtziou, L., Liakakou, E., Stavroulas, I., Theodosi, C., Zarmpas, P., Psiloglou, B., Sciare, J., Maggos, T., Bairachtari, K., Bougiatioti, A., Gerasopoulos, E., Sarda-Estève, R., Bonnaire, N., and Mihalopoulos, N.: Multi-tracer approach to characterize domestic wood burning in Athens (Greece) during wintertime, Atmos. Environ., 148, 89-101, https://doi.org/10.1016/j.atmosenv.2016.10.011, 2017.

Fuller, G. W., Sciare, J., Lutz, M., Moukhtar, S., and Wagener, S.: New directions: time to tackle urban wood burning?, Atmos. Environ., 68, 295-296, https://doi.org/10.1016/j.atmosenv.2012.11.045, 2013.

Fuller, G. W., Tremper, A. H., Baker, T. D., Yttri, K. E., and Butterfield, D.: Contribution of wood burning to $\mathrm{PM}_{10}$ in London, Atmos. Environ., 87, 87-94, https://doi.org/10.1016/j.atmosenv.2013.12.037, 2014.

Gao, Y., Zhang, M., Liu, Z., Wang, L., Wang, P., Xia, X., Tao, M., and Zhu, L.: Modeling the feedback between aerosol and meteorological variables in the atmospheric boundary layer during a severe fog-haze event over the North China Plain, Atmos. Chem. Phys., 15, 4279-4295, https://doi.org/10.5194/acp15-4279-2015, 2015.
Gerasopoulos, E., Gratsea, M., Liakakou, E., Lianou, M., Psiloglou, B., Kappos, N., Kambezidis, H., and Mihalopoulos, N.: An overview of biomass burning impacts on Athens air quality and analysis of its increasing significance, in: Perspectives on Atmospheric Sciences, edited by: Karacostas,T., Bais, A., and Nastos, P. T., Springer International Publishing, 1111-1116, 2017.

Gianini, M. F. D., Piot, C., Herich, H., Besombes, J.-L., Jaffrezo, J.L., and Hueglin, C.: Source apportionment of $\mathrm{PM}_{10}$, organic carbon and elemental carbon at Swiss sites: an intercomparison of different approaches, Sci. Total Environ., 454-455, 99-108, https://doi.org/10.1016/j.scitotenv.2013.02.043, 2013.

Gratsea, M., Vrekoussis, M., Richter, A., Wittrock, F., Schönhardt, A., Burrows, J., Kazadzis, S., Mihalopoulos, N., and Gerasopoulos, E.: Slant column MAX-DOAS measurements of nitrogen dioxide, formaldehyde, glyoxal and oxygen dimer in the urban environment of Athens, Atmos. Environ., 135, 118-131, https://doi.org/10.1016/j.atmosenv.2016.03.048, 2016.

Gon, H. D. van der, Beevers, S., D’Allura, A., Finardi, S., Honoré, C., Kuenen, J., Perrussel, O., Radice, P., Theloke, J., Uzbasich, M., and Visschedijk, A.: Discrepancies between top-down and bottom-up emission inventories of megacities: the causes and relevance for modeling concentrations and exposure, in: Air Pollution Modeling and its Application XXI, Springer, Dordrecht, 199-204, 2011.

Gu, J., Schnelle-Kreis, J., Pitz, M., Diemer, J., Reller, A., Zimmermann, R., Soentgen, J., Peters, A., and Cyrys, J.: Spatial and temporal variability of $\mathrm{PM}_{10}$ sources in Augsburg, Germany, Atmos. Environ., 71, 131-139, https://doi.org/10.1016/j.atmosenv.2013.01.043, 2013.

Hellén, H., Hakola, H., Haaparanta, S., Pietarila, H., and Kauhaniemi, M.: Influence of residential wood combustion on local air quality, Sci. Total Environ., 393, 283-290, https://doi.org/10.1016/j.scitotenv.2008.01.019, 2008.

Herich, H., Gianini, M. F. D., Piot, C., Močnik, G., Jaffrezo, J.-L., Besombes, J.-L., Prévôt, A. S. H., and Hueglin, C.: Overview of the impact of wood burning emissions on carbonaceous aerosols and PM in large parts of the Alpine region, Atmos. Environ., 89, 64-75, https://doi.org/10.1016/j.atmosenv.2014.02.008, 2014.

Hess, M., Koepke, P., and Schult, I.: Optical properties of aerosols and clouds: the software package OPAC, B. Am. Meteorol. Soc., 79, 831-844, https://doi.org/10.1175/15200477(1998)079<0831:OPOAAC >2.0.CO;2, 1998.

Hovorka, J., Pokorná, P., Hopke, P. K., Křůmal, K., Mikuška, P., and Píšová, M.: Wood combustion, a dominant source of winter aerosol in residential district in proximity to a large automobile factory in Central Europe, Atmos. Environ., 113, 98-107, https://doi.org/10.1016/j.atmosenv.2015.04.068, 2015.

IIASA International Institute for Applied Systems Analysis: GAINS detailed emissions by source and activity, PRIMES baseline scenario 2009, available at: http:/gains.iiasa.ac.at/gains/ EUN/index.login?logout, last access: 19 June 2012.

Janssen, N., Gerlofs-Nijland, M., Lanki, T., Salonen, R., Cassee, F., Hoek, G., Fischer, P., Brunekreef, B., and Krzyzanowski, M.: Health effects of black carbon, World Health Organization, 2012.

Kanakidou, M., Pandis, S. N., Barnes, I., Dentener, F. J., Facchini, M. C., Van Dingenen, R., Ervens, B., Nenes, A., Nielsen, C. J., Swietlicki, E., Putaud, J. P., Balkanski, Y., Fuzzi, S., Horth, J., Moortgat, G. K., Winterhalter, R., 
Myhre, C. E. L., Tsigaridis, K., Vignati, E., Stephanou, E. G., and Wilson, J.: Organic aerosol and global climate modelling: a review, Atmos. Chem. Phys., 5, 1053-1123, https://doi.org/10.5194/acp-5-1053-2005, 2005.

Knote, C. and Brunner, D.: An advanced scheme for wet scavenging and liquid-phase chemistry in a regional online-coupled chemistry transport model, Atmos. Chem. Phys., 13, 1177-1192, https://doi.org/10.5194/acp-13-1177-2013, 2013.

Knote, C., Brunner, D., Vogel, H., Allan, J., Asmi, A., Äijälä, M., Carbone, S., van der Gon, H. D., Jimenez, J. L., KiendlerScharr, A., Mohr, C., Poulain, L., Prévôt, A. S. H., Swietlicki, E., and Vogel, B.: Towards an online-coupled chemistry-climate model: evaluation of trace gases and aerosols in COSMO-ART, Geosci. Model Dev., 4, 1077-1102, https://doi.org/10.5194/gmd4-1077-2011, 2011.

Krall, J. R., Anderson, G. B., Dominici, F., Bell, M. L., and Peng, R. D.: Short-term exposure to particulate matter constituents and mortality in a national study of US urban communities, Environ. Health Persp., 121, 1148-1153, https://doi.org/10.1289/ehp.1206185, 2013.

Kuenen, J. J. P., Visschedijk, A. J. H., Jozwicka, M., and Denier van der Gon, H. A. C.: TNO-MACC_II emission inventory; a multi-year (2003-2009) consistent high-resolution European emission inventory for air quality modelling, Atmos. Chem. Phys., 14, 10963-10976, https://doi.org/10.5194/acp-14-109632014, 2014.

Kuenen, J., Denier van der Gon, H., Visschedijk, A., and van der Brugh, H.: High resolution European emission inventory for the years 2003-2007, Utrecht, TNO-report TNO-060-UT-201100588, 2011.

Lipsett, M. J., Ostro, B. D., Reynolds, P., Goldberg, D., Hertz, A., Jerrett, M., Smith, D. F., Garcia, C., Chang, E. T., and Bernstein, L.: Long-term exposure to air pollution and cardiorespiratory disease in the California Teachers Study Cohort, Am. J. Resp. Crit. Care, 184, 828-835, https://doi.org/10.1164/rccm.201012-2082OC, 2011.

López-Aparicio, S., Guevara, M., Thunis, P., Cuvelier, K., and Tarrasón, L.: Assessment of discrepancies between bottom-up and regional emission inventories in Norwegian urban areas, Atmos. Environ., 154, 285-296, https://doi.org/10.1016/j.atmosenv.2017.02.004, 2017.

Lundgren, K., Vogel, B., Vogel, H., and Kottmeier, C.: Direct radiative effects of sea salt for the Mediterranean region under conditions of low to moderate wind speeds, J. Geophys. Res.-Atmos., 118, 1906-1923, https://doi.org/10.1029/2012JD018629, 2013.

Maenhaut, W., Vermeylen, R., Claeys, M., Vercauteren, J., Matheeussen, C., and Roekens, E.: Assessment of the contribution from wood burning to the $\mathrm{PM}_{10}$ aerosol in Flanders, Belgium, Sci. Total Environ., 437, 226-236, https://doi.org/10.1016/j.scitotenv.2012.08.015, 2012.

Majewski, D., Liermann, D., Prohl, P., Ritter, B., Buchhold, M., Hanisch, T., Paul, G., Wergen, W., and Baumgardner, J.: The operational global icosahedral-hexagonal gridpoint model GME: description and high-resolution tests, Mon. Weather Rev., 130, 319-338, https://doi.org/10.1175/15200493(2002)130<0319:TOGIHG>2.0.CO;2, 2002.

Maricq, M. M.: Examining the relationship between black carbon and soot in flames and engine exhaust, Aerosol Sci. Tech., 48, 620-629, https://doi.org/10.1080/02786826.2014.904961, 2014.
Mishra, A. K., Klingmueller, K., Fredj, E., Lelieveld, J., Rudich, Y., and Koren, I.: Radiative signature of absorbing aerosol over the eastern Mediterranean basin, Atmos. Chem. Phys., 14, 72137231, https://doi.org/10.5194/acp-14-7213-2014, 2014.

Mishra, A. K., Koren, I., and Rudich, Y.: Effect of aerosol vertical distribution on aerosol-radiation interaction: a theoretical prospect, Heliyon, 1, https://doi.org/10.1016/j.heliyon.2015.e00036, 2015.

Molnar, P., Gustafson, P., Johannesson, S., Boman, J., Barregard, L., and Sallsten, G.: Domestic wood burning and PM trace elements: Personal exposures, indoor and outdoor levels, Atmos. Environ., 39, 2643-2653, https://doi.org/10.1016/j.atmosenv.2005.01.016, 2005.

Nightingale, P. D., Malin, G., Law, C. S., Watson, A. J., Liss, P. S., Liddicoat, M. I., Boutin, J., and Upstill-Goddard, R. C.: In situ evaluation of air-sea gas exchange parameterizations using novel conservative and volatile tracers, Global Biogeochem. Cy., 14, 373-387, https://doi.org/10.1029/1999GB900091, 2000.

Novakov, T., Menon, S., Kirchstetter, T. W., Koch, D., and Hansen, J. E.: Aerosol organic carbon to black carbon ratios: analysis of published data and implications for climate forcing, J. Geophys. Res., 110, D21205, https://doi.org/10.1029/2005JD005977, 2005.

Ostro, B., Lipsett, M., Reynolds, P., Goldberg, D., Hertz, A., Garcia, C., Henderson, K. D., and Bernstein, L.: Long-term exposure to constituents of fine particulate air pollution and mortality: results from the California teachers study, Environ. Health Persp., 118, 363-369, https://doi.org/10.1289/ehp.0901181, 2009.

Panicker, A. S., Pandithurai, G., Safai, P. D., and Kewat, S.: Observations of enhanced aerosol longwave radiative forcing over an urban environment, Geophys. Res. Lett., 35, L04817, https://doi.org/10.1029/2007GL032879, 2008.

Paraskevopoulou, D., Liakakou, E., Gerasopoulos, E., Theodosi, C., and Mihalopoulos, N.: Long-term characterization of organic and elemental carbon in the $\mathrm{PM}_{2.5}$ fraction: the case of Athens, Greece, Atmos. Chem. Phys., 14, 13313-13325, https://doi.org/10.5194/acp-14-13313-2014, 2014.

Paraskevopoulou, D., Liakakou, E., Gerasopoulos, E., and Mihalopoulos, N.: Sources of atmospheric aerosol from long-term measurements (5 years) of chemical composition in Athens, Greece, Sci. Total Environ., 527, 165-178, https://doi.org/10.1016/j.scitotenv.2015.04.022, 2015.

Piazzalunga, A., Belis, C., Bernardoni, V., Cazzuli, O., Fermo, P., Valli, G., and Vecchi, R.: Estimates of wood burning contribution to PM by the macro-tracer method using tailored emission factors, Atmos. Environ., 45, 6642-6649, https://doi.org/10.1016/j.atmosenv.2011.09.008, 2011.

Pio, C., Cerqueira, M., Harrison, R. M., Nunes, T., Mirante, F., Alves, C., Oliveira, C., Sanchez de la Campa, A., Artiñano, B., and Matos, M.: OC / EC Ratio Observations in Europe: Re-thinking the approach for apportionment between primary and secondary organic carbon, Atmos. Environ., 45, 6121-6132, 2011.

Puxbaum, H., Caseiro, A., Sánchez-Ochoa, A., Kasper-Giebl, A., Claeys, M., Gelencsér, A., Legrand, M., Preunkert, S., and Pio, C.: Levoglucosan levels at background sites in Europe for assessing the impact of biomass combustion on the European aerosol background, J. Geophys. Res., 112, https://doi.org/10.1029/2006JD008114, 2007. 
Rémy, S., Benedetti, A., Bozzo, A., Haiden, T., Jones, L., Razinger, M., Flemming, J., Engelen, R. J., Peuch, V. H., and Thepaut, J. N.: Feedbacks of dust and boundary layer meteorology during a dust storm in the eastern Mediterranean, Atmos. Chem. Phys., 15, 12909-12933, https://doi.org/10.5194/acp-1512909-2015, 2015.

Rieger, D., Bangert, M., Kottmeier, C., Vogel, H., and Vogel, B.: Impact of aerosol on post-frontal convective clouds over Germany, Tellus B, 66, 22528, https://doi.org/10.3402/tellusb.v66.22528, 2014

Riemer, N., Vogel, H., Vogel, B., and Fiedler, F.: Modeling aerosols on the mesoscale- $\gamma$ : treatment of soot aerosol and its radiative effects, J. Geophys. Res., 108, 4601, https://doi.org/10.1029/2003JD003448, 2003.

Ritter, B. and Geleyn, J.-F.: A comprehensive radiation scheme for numerical weather prediction models with potential applications in climate simulations, Mon. Weather Rev., 120, 303-325, https://doi.org/10.1175/15200493(1992)120<0303:ACRSFN>2.0.CO;2, 1992.

Rockel, B., Will, A., and Hense, A.: The regional climate model COSMO-CLM (CCLM), Meteorol. Z., 17, 347-348, https://doi.org/10.1127/0941-2948/2008/0309, 2008.

Saffari, A., Daher, N., Samara, C., Voutsa, D., Kouras, A., Manoli, E., Karagkiozidou, O., Vlachokostas, C., Moussiopoulos, N., Shafer, M. M., Schauer, J. J., and Sioutas, C.: Increased biomass burning due to the economic crisis in Greece and its adverse impact on wintertime air quality in Thessaloniki, Environ. Sci. Technol., 47, 13313-13320, https://doi.org/10.1021/es403847h, 2013.

Sarigiannis, D. A., Karakitsios, S. P., Kermenidou, M., Nikolaki, S., Zikopoulos, D., Semelidis, S., Papagiannakis, A., and Tzimou, R.: Total exposure to airborne particulate matter in cities: the effect of biomass combustion, Sci. Total Environ., 493, 795-805, https://doi.org/10.1016/j.scitotenv.2014.06.055, 2014.

Stanelle, T., Vogel, B., Vogel, H., Bäumer, D., and Kottmeier, C.: Feedback between dust particles and atmospheric processes over West Africa during dust episodes in March 2006 and June 2007, Atmos. Chem. Phys., 10, 10771-10788, https://doi.org/10.5194/acp-10-10771-2010, 2010.

Stockwell, W. R., Middleton, P., and Chang, J. S.: The second generation regional acid deposition model chemical mechanism for regional air quality modelling, J. Geophys. Res., 95, 16343-16367, 1990.

Szidat, S., Prévôt, A. S. H., Sandradewi, J., Alfarra, M. R., Synal, H.-A., Wacker, L., and Baltensperger, U.: Dominant impact of residential wood burning on particulate matter in Alpine valleys during winter, Geophys. Res. Lett., 34, L05820, https://doi.org/10.1029/2006GL028325, 2007.

Szidat, S., Ruff, M., Perron, N., Wacker, L., Synal, H.-A., Hallquist, M., Shannigrahi, A. S., Yttri, K. E., Dye, C., and Simpson, D.: Fossil and non-fossil sources of organic carbon (OC) and elemental carbon (EC) in Göteborg, Sweden, Atmos. Chem. Phys., 9, 1521-1535, https://doi.org/10.5194/acp-9-1521-2009, 2009.

Takemura, T., Nakajima, T., O., Dubovik, O., B. N., Holben, B. N., Kinne, S.,: Single-scattering albedo and radiative forcing of various aerosol species with a global three-dimensional model, J. Climate, 15, 333-352, 2002.
Timmermans, R. M. A., Denier van der Gon, H. A. C., Kuenen, J. J. P., Segers, A. J., Honoré, C., Perrussel, O., Builtjes, P. J. H., and Schaap, M.: Quantification of the urban air pollution increment and its dependency on the use of down-scaled and bottom-up city emission inventories, Urban Climate, 6, 4462, 2013.

Turpin, B. J. and Lim, H.-J.: Species Contributions to $\mathrm{PM}_{2.5}$ Mass Concentrations: Revisiting Common Assumptions for Estimating Organic Mass, Aerosol Sci. Technol., 35, 602-610, https://doi.org/10.1080/02786820119445, 2001.

van der Werf, G. R., Randerson, J. T., Giglio, L., Collatz, G. J., Mu, M., Kasibhatla, P. S., Morton, D. C., DeFries, R. S., Jin, Y., and van Leeuwen, T. T.: Global fire emissions and the contribution of deforestation, savanna, forest, agricultural, and peat fires (1997-2009), Atmos. Chem. Phys., 10, 11707-11735, https://doi.org/10.5194/acp-10-11707-2010, 2010.

Viana, M., Alastuey, A., Querol, X., Guerreiro, C., Vogt, M., Colette, A., Collet, S., Albinet, A., Fraboulet, I., Lacome J-M, Tognet, F., and de Leeuw, F.: ETC/ACM: Contribution of residential combustion to ambient air pollution and greenhouse gas emissions, ETC/ACM Technical Paper 2015/1, ETC/ACM, available at: http://acm.eionet.europa.eu/reports/ETCACM_TP_ 2015_1_residential_combustion,last access: April 2016.

Vogel, B., Fiedler, F., and Vogel, H.: Influence of topography and biogenic volatile organic compounds emission in the state of Baden-Wurttemberg on ozone concentrations during episodes of high air temperatures, J. Geophys. Res., 100, 22907-22928, 1995.

Vogel, B., Hoose, C., Vogel, H., and Kottmeier, C.: A model of dust transport applied to the Dead Sea Area, Meteorol. Z., 15, 611624, https://doi.org/10.1127/0941-2948/2006/0168, 2006.

Vogel, B., Vogel, H., Bäumer, D., Bangert, M., Lundgren, K., Rinke, R., and Stanelle, T.: The comprehensive model system COSMO-ART - Radiative impact of aerosol on the state of the atmosphere on the regional scale, Atmos. Chem. Phys., 9, 86618680, https://doi.org/10.5194/acp-9-8661-2009, 2009.

Vogel, H., Förstner, J., Vogel, B., Hanisch, T., Mühr, B., Schättler, U., and Schad, T.: Time-lagged ensemble simulations of the dispersion of the Eyjafjallajökull plume over Europe with COSMO-ART, Atmos. Chem. Phys., 14, 7837-7845, https://doi.org/10.5194/acp-14-7837-2014, 2014

Waked, A., Favez, O., Alleman, L. Y., Piot, C., Petit, J.-E., Delaunay, T., Verlinden, E., Golly, B., Besombes, J.-L., Jaffrezo, J.L., and Leoz-Garziandia, E.: Source apportionment of $\mathrm{PM}_{1} 0$ in a north-western Europe regional urban background site (Lens, France) using positive matrix factorization and including primary biogenic emissions, Atmos. Chem. Phys., 14, 3325-3346, https://doi.org/10.5194/acp-14-3325-2014, 2014.

Yli-Tuomi, T., Siponen, T., Taimisto, R. P., Aurela, M., Teinilä, K., Hillamo, R., Pekkanen, J., Salonen, R. O., and Lanki, T.: Impact of wood combustion for secondary heating and recreational purposes on particulate air pollution in a suburb in Finland, Environ. Sci. Technol., 49, 4089-4096, https://doi.org/10.1021/es5053683, 2015.

Young, D. E., Allan, J. D., Williams, P. I., Green, D. C., Harrison, R. M., Yin, J., Flynn, M. J., Gallagher, M. W., and Coe, H.: Investigating a two-component model of solid fuel organic aerosol in London: processes, $\mathrm{PM}_{1}$ contribu- 
tions, and seasonality, Atmos. Chem. Phys., 15, 2429-2443, https://doi.org/10.5194/acp-15-2429-2015, 2015.

Yttri, K. E., Dye, C., Slørdal, L. H., and Braathen, O.-A.: Quantification of monosaccharide anhydrides by liquid chromatography combined with mass spectrometry: application to aerosol samples from an urban and a suburban site influenced by smallscale wood burning, JAPCA J. Air Waste Ma., 55, 1169-1177, https://doi.org/10.1080/10473289.2005.10464720, 2005.
Zhang, B., Wang, Y., and Hao, J.: Simulating aerosol-radiationcloud feedbacks on meteorology and air quality over eastern China under severe haze conditionsin winter, Atmos. Chem. Phys., 15, 2387-2404, https://doi.org/10.5194/acp-152387-2015, 2015.

Zink, K., Pauling, A., Rotach, M. W., Vogel, H., Kaufmann, P., and Clot, B.: EMPOL 1.0: a new parameterization of pollen emission in numerical weather prediction models, Geosci. Model Dev., 6 , 1961-1975, https://doi.org/10.5194/gmd-6-1961-2013, 2013. 